\title{
Characterization of a Maltase from an Early-Diverged Non-Conventional Yeast Blastobotrys adeninivorans
}

\author{
Triinu Visnapuu $₫$, Aivar Meldre, Kristina Põšnograjeva, Katrin Viigand, Karin Ernits $®$ and \\ Tiina Alamäe *(1) \\ Department of Genetics, Institute of Molecular and Cell Biology, University of Tartu, Riia 23, \\ 51010 Tartu, Estonia; triinu.visnapuu@ut.ee (T.V.); aivarmeldre@gmail.com (A.M.); \\ kristina.poshnograjeva@gmail.com (K.P.); katrin.viigand@gmail.com (K.V.); karin.ernits@gmail.com (K.E.) \\ * Correspondence: tiina@alamae.eu
}

Received: 28 November 2019; Accepted: 30 December 2019; Published: 31 December 2019

\begin{abstract}
Genome of an early-diverged yeast Blastobotrys (Arxula) adeninivorans (Ba) encodes 88 glycoside hydrolases (GHs) including two $\alpha$-glucosidases of GH13 family. One of those, the rna_ARAD1D20130g-encoded protein (BaAG2; 581 aa) was overexpressed in Escherichia coli, purified and characterized. We showed that maltose, other maltose-like substrates (maltulose, turanose, maltotriose, melezitose, malto-oligosaccharides of DP 4-7) and sucrose were hydrolyzed by $B a A G 2$, whereas isomaltose and isomaltose-like substrates (palatinose, $\alpha$-methylglucoside) were not, confirming that $\mathrm{BaAG} 2$ is a maltase. $\mathrm{BaAG} 2$ was competitively inhibited by a diabetes drug acarbose $\left(\mathrm{K}_{\mathrm{i}}=0.8 \mu \mathrm{M}\right)$ and Tris $\left(\mathrm{K}_{\mathrm{i}}=70.5 \mu \mathrm{M}\right)$. BaAG2 was competitively inhibited also by isomaltose-like sugars and a hydrolysis product-glucose. At high maltose concentrations, BaAG2 exhibited transglycosylating ability producing potentially prebiotic di- and trisaccharides. Atypically for yeast maltases, a low but clearly recordable exo-hydrolytic activity on amylose, amylopectin and glycogen was detected. Saccharomyces cerevisiae maltase MAL62, studied for comparison, had only minimal ability to hydrolyze these polymers, and its transglycosylating activity was about three times lower compared to $B a A G 2$. Sequence identity of $B a A G 2$ with other maltases was only moderate being the highest (51\%) with the maltase MalT of Aspergillus oryzae.
\end{abstract}

Keywords: Arxula adeninivorans; glycoside hydrolase; $\alpha$-glucosidase; maltose; panose; amylopectin; glycogen; inhibition by Tris; transglycosylation

\section{Introduction}

A non-conventional yeast Blastobotrys adeninivorans (syn. Arxula adeninivorans) belongs to a basal clade of Saccharomycotina subphylum and diverged in the evolution of fungi long before Saccharomyces [1-5]. A recent study states that the divergence of basal Saccharomycotina from Saccharomyces cerevisiae took place between 200 and 400 million years ago [4].

B. adeninivorans has several biotechnologically relevant properties: accumulation of lipids [6], salt tolerance, temperature-induced filamentation that promotes protein secretion and the ability to use a wide range of carbon and nitrogen sources, including purines, tannin and butanol, that are unusual nutrients for yeasts $[2,7]$. B. adeninivorans has been engineered for butanol production, applied in kits for the detection of hormones and dioxine in water as well as for manufacturing of tannase and cutinases [7]. Some other enzymes of B. adeninivorans have also been investigated, including alcohol dehydrogenase [8], extracellular glucoamylase [9] and invertase [10]. A highly active endo-inulinase of $B$. adeninivorans was cloned and recently characterized [11]. The genome of B. adeninivorans was sequenced in 2014 [2]. 
The genes potentially encoding $\alpha$-glucosidases in the genomes of non-conventional yeasts were analysed in Viigand et al. [12]. The genes encoding two putative $\alpha$-glucosidases designated as AG1 and AG2 were revealed in genome of $B$. adeninivorans. In the genomes of most yeasts addressed in Viigand et al. [12], the $\alpha$-glucosidase genes resided in maltose utilization $(M A L)$ clusters, whereas no $M A L$ clusters were detected in B. adeninivorans.

$\alpha$-Glucosidases have been popular objects to study protein evolution and phylogenesis [13-16], but they also have a biotechnological value. Thus, some of them have a high transglycosylating activity thanks to which they produce prebiotic oligosaccharides and potential functional food ingredients such as panose, melezitose, isomelezitose and isomalto-oligosaccharides [17-21]. For example, the $\alpha$-glucosidase of $S$. cerevisiae produced isomelezitose from sucrose when the substrate concentration was high [21]. Transglycosylating ability of maltose by the $\alpha$-glucosidase of Xanthophyllomyces dendrorhous (syn. Phaffia rhodozyma) has been studied in detail, and synthesis of tri- and tetrasaccharides with $\alpha-1,6$ linkages was detected. This enzyme certainly has a biotechnological potential-it produced 3.6 times more transglycosylation products than the $S$. cerevisiae $\alpha$-glucosidase studied at the same conditions $[17,20]$.

Considering $\alpha$-glucosidases of yeasts, they have mostly been studied in S. cerevisiae as these enzymes are crucial in baking and brewing [22]. S. cerevisiae has two types of $\alpha$-glucosidases-maltases (EC 3.2.1.20) and isomaltases (EC 3.2.1.10)—that differ for substrate specificity. Maltases degrade maltose and maltose-like sugars, i.e., maltotriose, turanose and maltulose, but cannot degrade isomaltose and isomaltose-like sugars ( $\alpha-1,6$ linkages) such as palatinose. Both types of enzymes hydrolyze sucrose and a synthetic substrate $p$-nitrophenyl- $\alpha$-D-glucopyranoside ( $p$ NPG) $[15,16,23,24]$. At the same time, some yeasts such as Ogataea polymorpha and Scheffersomyces stipitis, have promiscuous maltase-isomaltases that hydrolyze maltose- and isomaltose-like substrates $[12,16,25]$.

In the current work, we expressed heterologously in Escherichia coli and biochemically characterized the $\alpha$-glucosidase BaAG2 of B. adeninivorans encoded by rna_ARAD1D20130g. We confirmed that $B a A G 2$ is a maltase with a considerable transglycosylating activity. Not typical for yeast maltases, $\mathrm{BaAG} 2$ had exo-hydrolytic activity on amylose, amylopectin and glycogen. BaAG2 is the first maltase characterized from B. adeninivorans.

\section{Results}

\subsection{In Silico Analysis of $B a A G 2$}

According to annotations provided at the MycoCosm website [26], the genome of Blastobotrys (Arxula) adeninivorans [2] encodes 185 carbohydrate-active enzymes, including 88 glycoside hydrolases (GHs) assigned to different families. When mining the genome of B. adeninivorans [2] for the genes related to maltose hydrolysis, we found two genes encoding intracellular GH13 family proteins. Respective proteins were designated as AG1 and AG2 [12]. In MycoCosm, the AG1 was annotated as a protein similar to maltase Mal1 of Schizosaccharomyces pombe and the AG2 as similar to maltases of filamentous fungi Aspergillus and Penicillium. Both of these proteins were predicted to lack a signal peptide and to locate intracellularly. We confirmed this by using the SignalP program (see Materials and Methods). Aside from these two GH13 proteins, three putative extracellular $\alpha$-glucosidases of GH31 family were detected in B. adeninivorans genome (see Table S1 of Supplementary Materials). Table S1 also includes two B. adeninivorans enzymes that have been experimentally studied: a secreted invertase AINV belonging to GH31 family [10] and a secreted glucoamylase [9] of GH15 family.

Substrate specificity of $\alpha$-glucosidases can be in silico predicted based on so-called amino acid signature-a set of amino acids that locate in the vicinity of the substrate-binding pocket $[12,15,27,28]$. The upper panel of Figure 1 shows the amino acid signature of O. polymorpha maltase-isomaltase MAL1, S. cerevisiae maltase MAL62, isomaltase IMA1, and B. adeninivorans AG2. The amino acids of these proteins corresponding to Val216 of ScIMA1 are shown inside a red frame as this position is considered of key importance in selective substrate binding [28]. 


\begin{tabular}{|c|c|c|c|c|c|c|c|c|c|c|}
\hline \multirow{2}{*}{ Enzyme } & \multicolumn{9}{|c|}{ Amino acid signature (numbering according to ScIMA1) } & \multirow{2}{*}{ Function } \\
\hline & 158 & 216 & 217 & 218 & 219 & 278 & 279 & 307 & 411 & \\
\hline OpMAL1 & $\mathrm{F}$ & T & A & G & L & V & G & D & $\mathrm{N}$ & Maltase-isomaltase \\
\hline ScMAL62 & $\mathrm{F}$ & T & A & G & L & V & A & $\mathrm{E}$ & D & Maltase \\
\hline ScIMA1 & Y & V & G & S & L & M & Q & D & $\mathrm{E}$ & Isomaltase \\
\hline BaAG2 & $Y$ & $\mathrm{~T}$ & V & $Q$ & I & G & $S$ & $\mathrm{R}$ & $\mathrm{N}$ & $\begin{array}{l}\text { Maltase or } \\
\text { Maltase-isomaltase }\end{array}$ \\
\hline
\end{tabular}

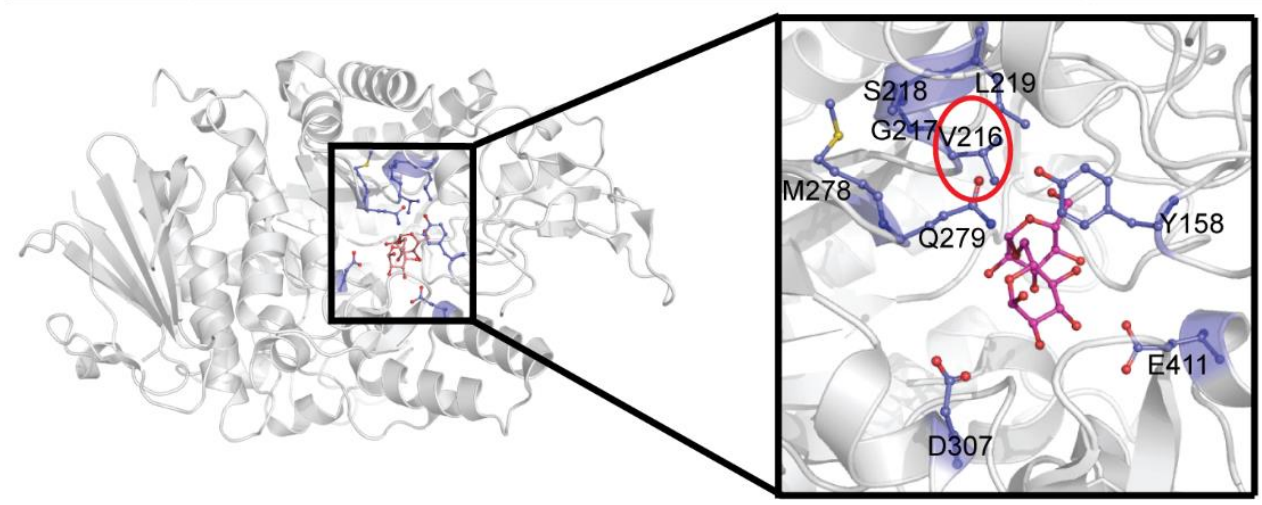

Figure 1. Amino acid signature of yeast $\alpha$-glucosidases, including B. adeninivorans AG2 (upper panel) and their designation on the three-dimensional (3D) structure of $S$. cerevisiae isomaltase IMA1 in complex with isomaltose (RCSB Protein Data Bank, PDB: 3AXH [29]) (lower panel). Location of Val216 in the structure is marked with a red circle.

We then visualized the S. cerevisiae IMA1 structure in complex with isomaltose (PDB: 3AXH) [29] using PyMol [30] in order to display all these amino acids (Figure 1, lower panel). In BaAG2, a Thr is present at position of Val216 and therefore we predicted that this enzyme is most probably a maltase. However, as maltase-isomaltases also have a Thr at that position (Figure 1, upper panel; [12,16]), based on the amino acid signature, $B a$ AG2 may also be a promiscuous enzyme with a wide substrate spectrum like O. polymorpha MAL1.

Figure 2 presents fragments of sequence comparison of $B a \mathrm{AG} 2$ with those of five experimentally studied maltases from GH13 family: two from bacteria, two from yeasts and one from a filamentous fungus Aspergillus. The identity matrix of these proteins is presented in Supplementary Materials (Table S2). Though the proteins aligned sufficiently well over the entire sequence, BaAG2 showed only moderate sequence identity with the other maltases ranging from $35 \%$ with Halomonas sp. H11 $\alpha$-glucosidase to $51 \%$ with Aspergillus oryzae maltase MalT (Table S2). In silico assay of $\alpha$-glucosidases of non-conventional yeasts [12] identified a putative $\alpha$-glucosidase protein AG1 of Lipomyces starkeyi as the closest homologue (50\% identity) of BaAG2. The amino acid signature of the Lipomyces protein was YTVNKLSHE, and it was, therefore, predicted as a maltase [12].

The GH13 enzymes use an Asp (D) as a nucleophile and a Glu (E) as an acid-base catalyst [31]. Additionally, an Asp of the conserved 'NHD' motif serves as a transition state stabilizer [32]. In the BaAG2 protein, Asp216 was predicted as a nucleophile, Glu274 as an acid-base catalyst and Asp348 as a stabilizer (Figure 2). Thr217 is located next to the catalytic nucleophile Asp216 in BaAG2 (Figure 2). In maltases and maltase-isomaltases, either Thr or Ala is present at respective position, whereas in isomaltases, a Val is present $[12,15,27,28]$, indicating that a Val residue at this position interferes with hydrolysis of maltose-like substrates. Indeed, if respective Thr was substituted with Val in O. polymorpha maltase-isomaltase, utilization of maltose-like sugars was severely hampered [16]. 
Furthermore, after substitution of Val216 in S. cerevisiae IMA1 with Thr, the isomaltase IMA1 gained the ability to hydrolyze maltose $[28,29]$.

\begin{tabular}{|c|c|c|c|}
\hline BaAG2 & DAILFWLERG & IDGFRIDTVQ & 219 \\
\hline SpMal1 & -ILRFWLDRG & VDGFRLDAIN & 215 \\
\hline SCMAL 62 & SAVGFWLDHG & VDGFRIDTAG & 217 \\
\hline GsAG & -MINWWLDKG & IDGFRIDAIS & 202 \\
\hline HaAG & -NMRFWLDLG & VDGFRLDTVN & 205 \\
\hline AoMalT & SAMEFWLQKG & VDGFRVDTVN & 213 \\
\hline $\mathrm{Cc}$ & $:: \star \star: \star$ & $: \star \star \star \star: \star:$ & \\
\hline BaAG2 & SKYD-IMTVG & EGS-PPSLEK & 282 \\
\hline SpMal1 & TEYD-AFSVG & EMPYVLDTNE & 278 \\
\hline ScMAL 62 & DGRE-IMRVG & EVA--HGSDN & 283 \\
\hline GsAG & ARYD-IMTVG & EAN-GVTVDE & 264 \\
\hline HaAG & DEYPGTTTVG & EIGDDNPLER & 280 \\
\hline AoMalT & AKYD-AMTVG & ELPNTHTVDG & 276 \\
\hline $\mathrm{Cc}$ & $\star \star$ & * & \\
\hline BaAG2 & TTFFLENHDS & GRSISRFASD & 359 \\
\hline SpMal1 & NASFIENHDQ & TRTVSRYLSD & 357 \\
\hline ScMAL 62 & ATTYIENHDQ & ARSITRFADD & 360 \\
\hline GsAG & NALFLENHDL & PRSVSTWGND & 337 \\
\hline HaAG & PCWATSNHDV & VRSATRWGAD & 344 \\
\hline AoMalT & STVFTENHDQ & GRSVSRFGSE & 356 \\
\hline & & & \\
\hline
\end{tabular}

Figure 2. Fragments of sequence alignment of six maltases. BaAG2, Blastobotrys adeninivorans AG2 (580 aa); SpMal1, Schizosaccharomyces pombe Mal1 (579 aa, NP_595063.1) [33]; ScMAL62, Saccharomyces cerevisiae MAL62 (584 aa, P07265) [23]; GsAG, Geobacillus stearothermophilus exo- $\alpha$-1,4-glucosidase (555 aa, BAA12704.1) [34]; HaAG, Halomonas sp. H11 $\alpha$-glucosidase (538 aa, BAL49684.1) [35]; AoMalT, Aspergillus oryzae maltase MalT (574 aa, XP_001825184.1) [36]. Highlights: catalytic nucleophile (turquoise), acid-base catalyst (green), a transition state stabilizer (yellow) and a residue crucial for substrate specificity (red). Cc, Clustal consensus. Marking below the sequence alignment is according to Clustal consensus showing conservation: ${ }^{*}$ positions with fully conserved residue; : positions with residues of strongly similar properties; . positions with residues of weakly similar properties.

\subsection{Maltose-Like and Isomaltose-Like Sugars Are Growth Substrates for B. adeninivorans}

According to the information present in the CBS-KNAW culture collection [37], B. adeninivorans CBS 8244 used in current work assimilates following $\alpha$-glucosidic sugars: maltose, sucrose, melezitose, trehalose and $\alpha$-MG. Of those, melezitose is a maltose-like sugar, and $\alpha-\mathrm{MG}$ (a synthetic analogue of isomaltose [38]) is an isomaltose-like sugar. Glucose and many other monosaccharides are also assimilated. We asked if $B$. adeninivorans can also assimilate some other $\alpha$-glucosidic sugars. We cultivated B. adeninivorans on Yeast Nitrogen Base (YNB) mineral medium containing $2 \mathrm{~g} / \mathrm{L}$ of sugars indicated in Figure 3, and evaluated growth according to an optical density (OD) of $600 \mathrm{~nm}$ achieved by $24 \mathrm{~h}$ of growth (Figure 3). Our assay confirmed that five above-mentioned $\alpha$-glucosidic sugars were indeed all assimilated. In addition, maltotriose, maltulose, turanose (maltose-like sugars) as well as isomaltose and palatinose (an isomaltose-like sugar) were identified as new growth substrates for this yeast. Thus, B. adeninivorans grows on both maltose-like and isomaltose-like sugars, meaning that it should possess enzymes for the hydrolysis of both types of sugars. 


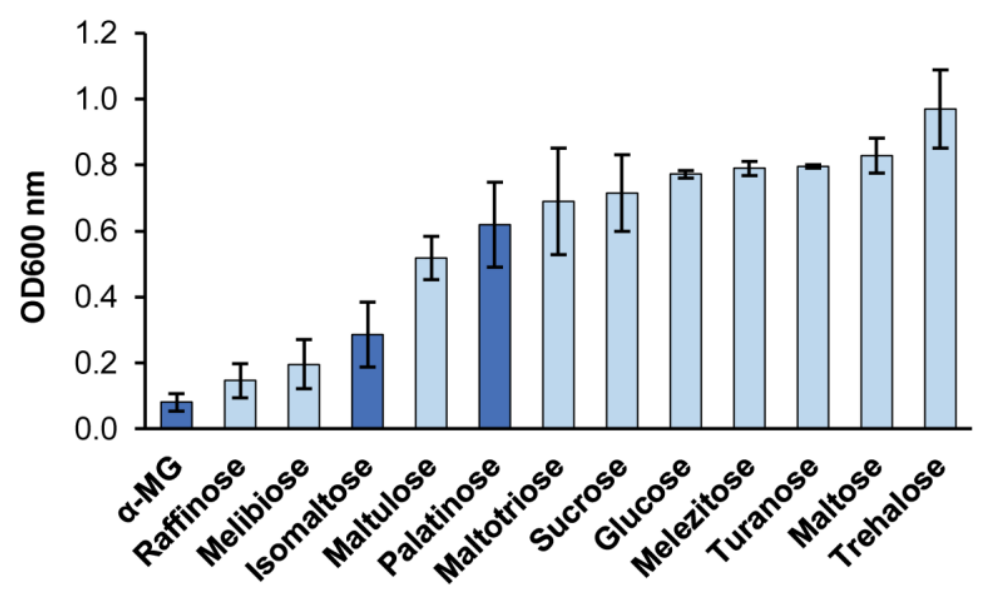

Figure 3. Growth of B. adeninivorans on sugars (supplemented at $2 \mathrm{~g} / \mathrm{L}$ ) evaluated by an optical density (OD) of the culture at $600 \mathrm{~nm}$ achieved by $24-\mathrm{h}$ cultivation on a microplate at $37^{\circ} \mathrm{C}$. Isomaltose and isomaltose-like sugars are indicated by dark blue bars. Error bars are representing standard deviations (SD) of two independent experiments with two replicates.

\subsection{Cloning of the $\mathrm{Ba} A G 2$ Gene and Heterologous Expression of the $\mathrm{BaAG2}$ Enzyme}

The $\mathrm{BaAG} 2$ protein deduced from the gene is 580 aa long. The protein was predicted as intracellular-no secretion signal was detected by the SignalP program v. 5.0 [39]. BaAG2 was overexpressed in E. coli with the $\mathrm{His}_{6}$-tag in its C-terminus that enabled purification of the protein using $\mathrm{Ni}^{2+}$-affinity chromatography. The calculated molecular weight of the protein was $67.9 \mathrm{kDa}$ and a prominent band of respective size was detected by electrophoresis of the lysate produced from induced E. coli cells overexpressing the $A G 2$ gene (Figure S1). The E. coli lysate exhibited catalytic activity of $1 \mathrm{mM} p \mathrm{NPG}$ hydrolysis at $30{ }^{\circ} \mathrm{C}(71 \mathrm{U} / \mathrm{mg})$, which after purification of the protein increased 5.8 times, reaching $411.5 \mathrm{U} / \mathrm{mg}$.

\subsection{Properties of $\mathrm{Ba} A G 2$}

\subsubsection{Dependence of the BaAG2 Activity on Temperature and $\mathrm{pH}$. Thermal Stability of $B a \mathrm{AG} 2$}

The $\mathrm{pH}$ optimum of $\mathrm{BaAG} 2$ was in moderately acidic region-from 5.5 to 6.5 (Figure S2). At $\mathrm{pH}$ 7.5 , the activity was $81 \%$ from the maximum, and at $\mathrm{pH} 8.5$, it was decreased to $52 \%$. At $\mathrm{pH} 4.5$ and 4.4 , the respective values were 93 and $15 \%$. Thus, the activity of $B a A G 2$ was significantly reduced at $\mathrm{pH}$ values below 4.5 and over 8.5 (Figure S2). The $\mathrm{pH}$ optimum of the O. polymorpha maltase is 6.0-6.5 [40], of S. cerevisiae maltase 6.5-6.8 [23,24] and of Schizosaccharomyces pombe maltase 6.0 [33]. In the current work, we routinely used the buffer with $\mathrm{pH}$ of 6.5 to characterize substrate specificity, kinetics and other properties of the enzyme.

As shown in Figure 4 (left panel), catalytic activity of $B a A G 2$ was the highest at $45^{\circ} \mathrm{C}$ being $24 \%$ higher than activity measured at $30^{\circ} \mathrm{C}$ - the temperature we routinely used for enzyme activity assay. Figure 4 shows that at temperature over $50^{\circ} \mathrm{C}$, the activity of the enzyme rapidly declined. Thermal stability assay of $B a \mathrm{AG} 2$ indicated that the enzyme was rather thermolabile: if kept for $30 \mathrm{~min}$ at temperatures above $37^{\circ} \mathrm{C}$, its catalytic activity reduced significantly (Figure 4, right panel). Therefore, we routinely performed enzymatic assays at $30^{\circ} \mathrm{C}$ since some reactions (e.g., transglycosylation and polysaccharide degradation assays) were conducted up to several days. 

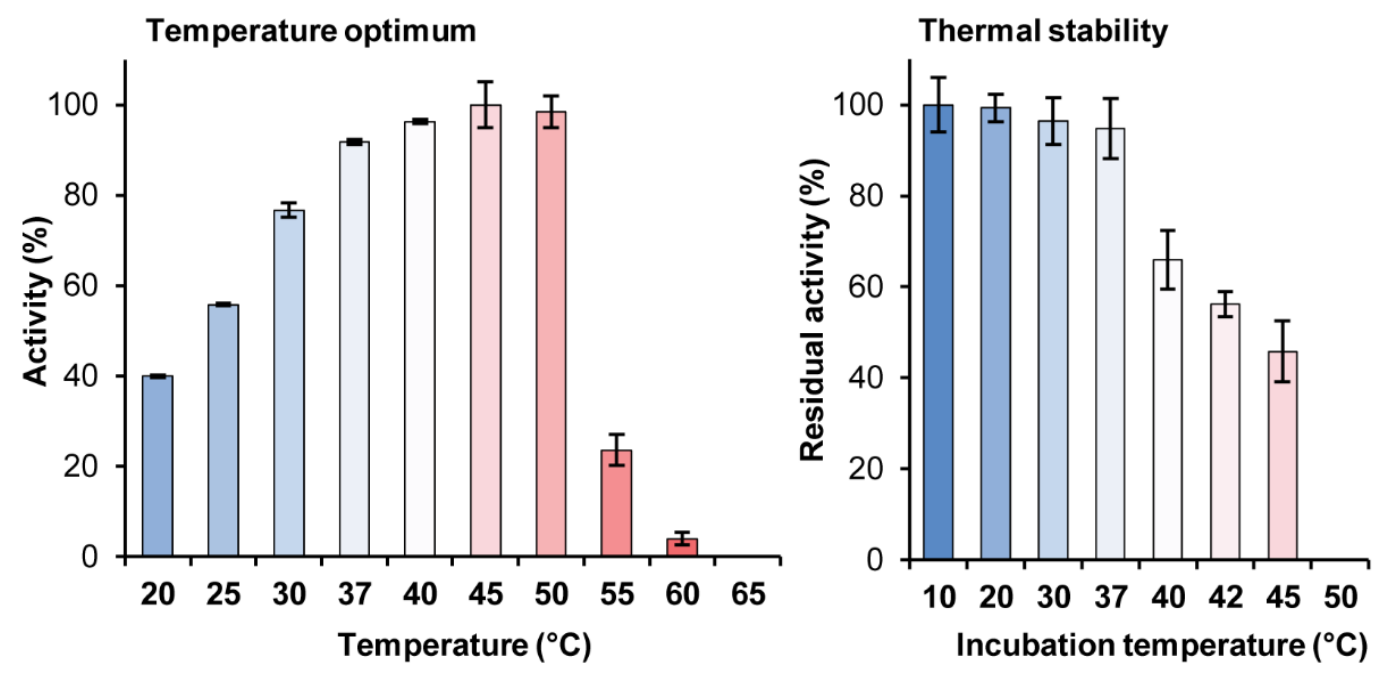

Figure 4. The effect of temperature on activity (left panel) and stability (right panel) of BaAG2. For the thermostability assay, the enzyme was incubated for $30 \mathrm{~min}$ at the indicated temperature and residual activity was determined at $30^{\circ} \mathrm{C}$ with $p$ NPG as a substrate (see Materials and Methods, paragraph 4.4. for details). SDs of two to three replicates at each temperature are shown by error bars.

\subsubsection{The Hydrolysis of Maltose and Maltose-Like Sugars}

We predicted in silico that $\mathrm{BaAG} 2$ is either maltase or maltase-isomaltase (see Figure 1). To find out which of the predictions was correct, the purified $B a A G 2$ protein was reacted with a selection of $100 \mathrm{mM}$ sugars and $1 \mathrm{mM} p$ NPG that serves as a substrate for maltases, isomaltases and maltase-isomaltases (Figure 5). According to our assay, BaAG2 could hydrolyze universal substrates ( $p$ NPG and sucrose), maltose and maltose-like sugars such as turanose, maltotriose, melezitose and maltulose. Isomaltose and isomaltose-like substrates palatinose and $\alpha$-methylglucoside were not hydrolyzed (Figure 5). Therefore, $B a \mathrm{AG} 2$ should be considered as a maltase.

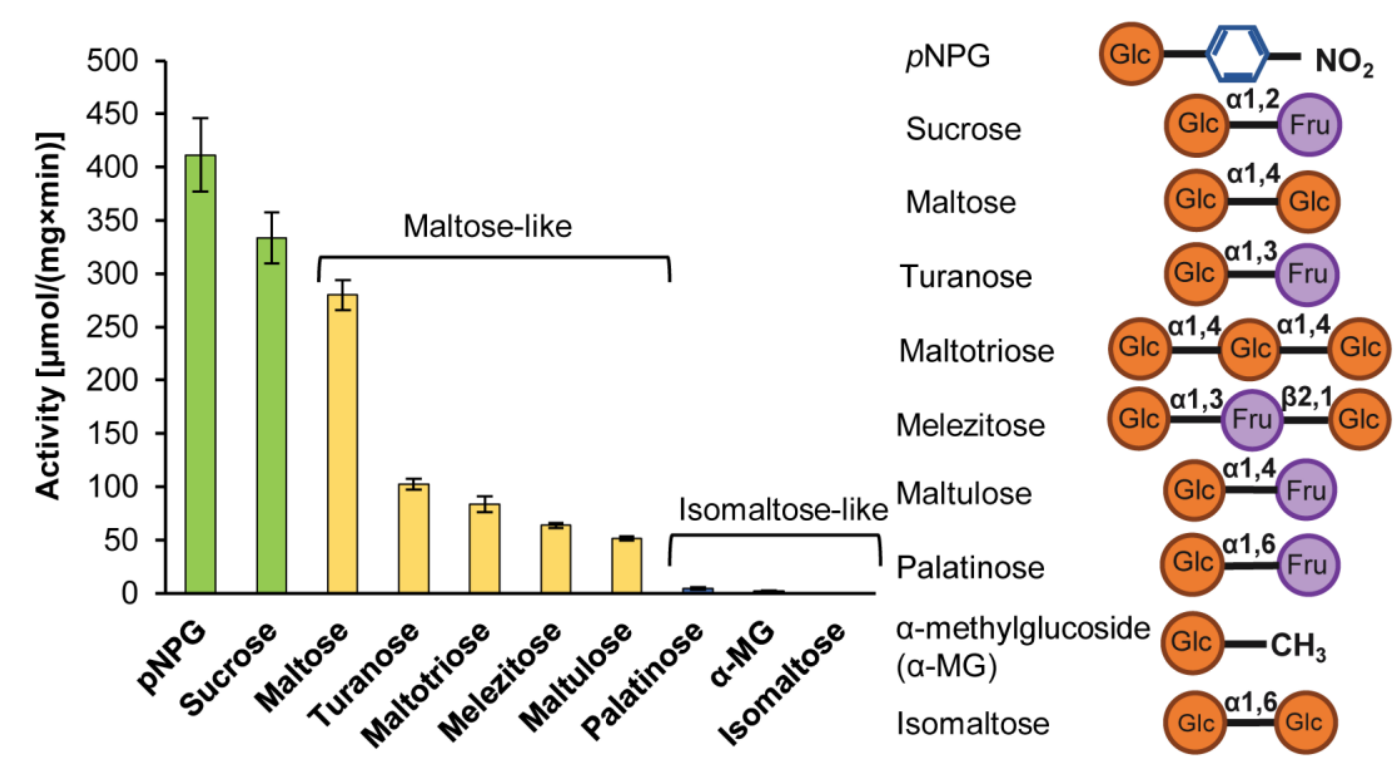

Figure 5. Activity of $\mathrm{BaAG} 2$ on $100 \mathrm{mM}$ sugars and $1 \mathrm{mM} p$ NPG. Universal substrates are indicated by green, maltose and maltose-like sugars by yellow, and isomaltose and isomaltose-like sugars by blue bars. The composition and linkage types of the tested substrates are indicated. SD values of three to five replicates on each substrate are indicated. 


\subsubsection{The Kinetic Parameters of Hydrolysis of Maltose, Maltose-Like and Universal Substrates}

We studied the kinetics of the hydrolysis of $p$ NPG, maltose, sucrose, maltotriose, melezitose, maltulose and turanose to calculate $\mathrm{K}_{\mathrm{m}}, \mathrm{V}_{\text {max }}, k_{\text {cat }}$ and catalytic efficiency $\left(k_{\mathrm{cat}} / \mathrm{K}_{\mathrm{m}}\right)$ values for these substrates. Results are presented in Table 1.

Table 1. $\mathrm{K}_{\mathrm{m}}, \mathrm{V}_{\max }, k_{\text {cat }}$ and $k_{\mathrm{cat}} / \mathrm{K}_{\mathrm{m}}$ values of hydrolysis of $p$ NPG and sugars by BaAG2.

\begin{tabular}{ccccc}
\hline Substrate & $\mathbf{K}_{\mathbf{m}} \pm \mathbf{S D}(\mathbf{m M})$ & $\begin{array}{c}\boldsymbol{V}_{\max } \pm \mathbf{S D} \\
(\mu \mathbf{m o l} / \mathbf{( m g} \times \mathbf{m i n}))\end{array}$ & $\boldsymbol{k}_{\text {cat }} \pm \mathbf{S D}(\mathbf{1} / \mathbf{s})$ & $\boldsymbol{k}_{\text {cat }} / \mathbf{K}_{\mathbf{m}}(\mathbf{1} /(\mathbf{m M} \times \mathbf{s}))$ \\
\hline$p$ NPG & $0.76 \pm 0.03$ & $751.3 \pm 14.5$ & $850.2 \pm 16.4$ & 1106.1 \\
Maltose & $25.8 \pm 1.6$ & $336.4 \pm 5.8$ & $380.7 \pm 6.5$ & 14.8 \\
Maltotriose & $32.5 \pm 3.3$ & $117.9 \pm 4.4$ & $133.5 \pm 5.0$ & 4.1 \\
Sucrose & $35.9 \pm 2.7$ & $412.4 \pm 8.9$ & $466.8 \pm 10.1$ & 13.0 \\
Turanose & $45.2 \pm 6.0$ & $190.1 \pm 10.4$ & $215.1 \pm 11.9$ & 7.6 \\
Maltulose & $7.8 \pm 1.0$ & $52.2 \pm 1.8$ & $59.1 \pm 2.1$ & 1.1 \\
Melezitose & $238.3 \pm 51.8$ & $231.0 \pm 31.8$ & $261.4 \pm 36.1$ & \\
\hline
\end{tabular}

* For the structure and linkage type of the substrates, see Figure 5. SD, standard deviation.

Table 1 shows that natural sugars, maltose and sucrose $(\alpha$-D-Glc- $(1 \rightarrow 2)-\beta$-D-Fru) were hydrolyzed by $B a A G 2$ with the highest catalytic efficiency $\left(k_{\text {cat }} / K_{\mathrm{m}}\right)$. Additionally, BaAG2 had a high affinity and activity towards a synthetic substrate $p \mathrm{NPG}$ - the $\mathrm{K}_{\mathrm{m}}$ for $p \mathrm{NPG}$ was $0.76 \mathrm{mM}$ and the $\mathrm{V}_{\max }$ over $750 \mathrm{U} / \mathrm{mg}$. Affinity of BaAG2 for maltose was slightly higher than for sucrose. From this aspect, BaAG2 differs from the maltases of S. cerevisiae [23,24] and Candida albicans [41], and also from the maltase-isomaltase of O. polymorpha [16,40,42], for which affinity for sucrose is about twice higher than for maltose. In contrast, the maltase of Schizosaccharomyces pombe prefers maltose to sucrose [33]. Among the substrates tested, the affinity and catalytic efficiency of BaAG2 was the lowest for melezitose. Thin layer chromatography (TLC) analysis showed that the glycosidic bond of turanose moiety of melezitose was hydrolyzed first, yielding sucrose and glucose as products (Figure S3). Similar mode of melezitose hydrolysis was earlier shown for the maltase-isomaltase of O. polymorpha [16]. Interestingly, isomelezitose was hydrolyzed by $\mathrm{BaAG} 2$ with release of palatinose (Figure S3).

We would like to emphasize that the activity of BaAG2 (Table 1) was higher compared to some of other studied maltases of yeasts and filamentous fungi. For example, its $V_{\max }$ on maltose was 7.5 times higher compared to S. cerevisiae maltase MAL62 [23], and over two times higher compared to maltase-isomaltase of O. polymorpha [16]. On the other hand, $\alpha$-glucosidases of X. dendrorhous and $A$. niveus preferred polysaccharides such as starch, amylopectin and glycogen, and their $k_{\text {cat }}$ values on maltose were respectively 25 and 28 times lower compared to the value of BaAG2 [43,44]. Catalytic constant of $\alpha$-glucosidase of $A$. niger on maltose was 144 1/s (2.6 times lower than $B a A G 2)$, but the affinity towards maltose was very high $(0.75 \mathrm{mM})$ [45]. Based on the literature, only one $\alpha$-glucosidase of yeast and filamentous fungi has much higher $k_{\text {cat }}$ on maltose than that of $B a \mathrm{AG}$ - the extracellular $\alpha$-glucosidase of Schizosaccharomyces pombe $\left(k_{\mathrm{cat}}=7091 / \mathrm{s}\right)[46]$.

\subsubsection{The Inhibition Studies of Acarbose, Tris, Isomaltose-Like Sugars and Glucose}

Having seen that isomaltose and isomaltose-like sugars are not hydrolyzed by BaAG2 (Figure 5), we measured inhibition of $p$ NPG hydrolysis reaction by these sugars as in [16]. Because maltases are usually strongly inhibited by glucose and acarbose, and much less by fructose [16], these substrates were also assayed as potential inhibitors of $B a A G 2$. When testing the effect of different buffers during the experiments, we noticed that the activity of $\mathrm{BaAG} 2$ was lost in Tris-HCl buffer. More precise assay of the effect of tris(hydroxymethyl)aminomethane (Tris) on BaAG2 revealed strong inhibition of the enzyme by this compound (Table 2). All tested compounds inhibited $p$ NPG hydrolysis competitively, and the most powerful inhibitors of $B a A G 2$ were acarbose, Tris and glucose. 
Table 2. $\mathrm{K}_{\mathrm{i}}$ values and inhibition mode for $B a \mathrm{AG} 2$ inhibitors of $p$ NPG hydrolysis.

\begin{tabular}{ccc}
\hline Inhibitor & $\mathbf{K}_{\mathbf{i}} \pm \mathbf{S D}(\mathbf{m M})$ & Inhibition Mode \\
\hline Palatinose & $1.4 \pm 0.1$ & Competitive \\
Isomaltose & $22.7 \pm 3.0$ & Competitive \\
$\alpha$-MG & $21.8 \pm 1.4$ & Competitive \\
Acarbose & $0.83 \pm 0.01^{*}$ & Competitive \\
Glucose & $0.86 \pm 0.05$ & Competitive \\
Fructose & $36.9 \pm 2.4$ & Competitive \\
Tris & $70.5 \pm 4.3^{*}$ & Competitive \\
\hline
\end{tabular}

* These values are given in $\mu \mathrm{M}$. SD, standard deviation.

We expected that binding of the substrates or competitive inhibitors of the enzyme should increase its thermostability. To confirm this, we conducted a differential scanning fluorimetry (DSF) assay of $\mathrm{BaAG} 2$ in the presence and absence of competing inhibitors as in $[16,47]$. Acarbose, palatinose, Tris and glucose (strong inhibitors of $p$ NPG hydrolysis by $\mathrm{BaAG} 2$ ) and fructose that inhibited the reaction only weakly (see Table 2 ) were used as ligands. The melting temperature $\left(T_{m}\right)$ values calculated from the DSF data are presented in Figure 6. The $\mathrm{T}_{\mathrm{m}}$ of $B a \mathrm{AG} 2$ without a ligand was similar to that of maltase-isomaltase MAL1 of O. polymorpha- $511^{\circ} \mathrm{C}$ [16]. Presence of acarbose (the strongest inhibitor of $B a A G 2)$ increased the $\mathrm{T}_{\mathrm{m}}$ of $\mathrm{BaAG} 2$ by $11.4^{\circ} \mathrm{C}$. Presence of Tris raised the $\mathrm{T}_{\mathrm{m}}$ value by $5.8^{\circ} \mathrm{C}$, and of glucose by $4.4{ }^{\circ} \mathrm{C}$. Fructose and palatinose had only a minor effect on the $\mathrm{T}_{\mathrm{m}}$ (Figure 6).

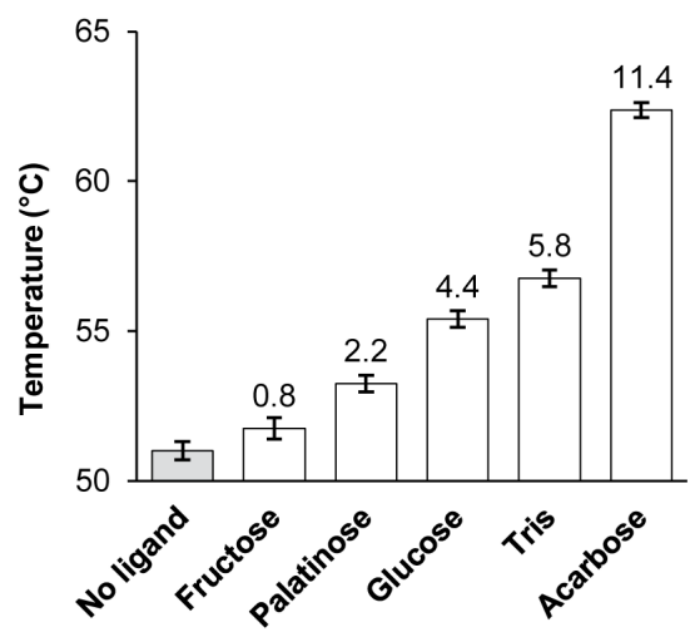

Figure 6. Thermostability of $B a A G 2$ in the presence and absence of indicated ligands. The $\mathrm{T}_{\mathrm{m}}$ value of unliganded $\mathrm{BaAG} 2$ (a grey bar) was $51^{\circ} \mathrm{C}$ and the increase of $\mathrm{T}_{\mathrm{m}}$ in the presence of a ligand is indicated above every bar. SDs of at least two independent experiments with two replicates at each condition are shown by error bars.

\subsubsection{The Hydrolysis of Malto-Oligosaccharides of DP 3 to 7}

We have earlier shown that $O$. polymorpha maltase-isomaltase MAL1 could use maltotriose and maltotetraose as a substrate, while malto-oligosaccharides (MOS) of higher degree of polymerization (DP) were not hydrolyzed [16]. We showed that MOS of DP3 (see Table1), DP4, DP5, DP6 and DP7 served as substrates for $B a \mathrm{AG} 2$ (Figure S4). Assay of reaction course indicated that exo-hydrolysis occurred-a glucose residue was stripped off from the oligomer. Activity on MOS was only moderate and a substantial proportion of it stayed unreacted even after extended $(22 \mathrm{~h})$ reaction time (see Figure S4). The MAL62 of S. cerevisiae that was assayed alongside could not hydrolyze MOS longer than maltotetraose (DP4) (Figure S4). 


\subsubsection{The Hydrolysis of Amylose, Amylopectin and Glycogen}

Surprisingly, we detected the ability of $B a A G 2$ to hydrolyze polysaccharides that is a rather exceptional feature among maltases. After we noticed that $B a A G 2$ could hydrolyze soluble starch with the release of glucose, we performed a more detailed assay testing the hydrolysis of a set of polymeric $\alpha$-glucans: amylose and amylopectin from potato, glycogen from oysters and dextrans of $\mathrm{M}_{\mathrm{W}} 20$ and $110 \mathrm{kDa}$. Commercial amylolytic enzymes amyloglycosidase (glucoamylase) from Aspergillus niger, and $\alpha$-amylase from Aspergillus oryzae and S. cerevisiae MAL62 were used as reference enzymes.

Hydrolysis of the polymers was evaluated according to the release of glucose and by TLC analysis of reaction products. The commercial enzymes hydrolyzed amylose, amylopectin and glycogen rapidly and with the expected pattern of products (Figure 7). Dextrans were hydrolyzed only by the amyloglycosidase, and the release of glucose was minimal. BaAG2 and ScMAL62 had no activity on dextrans. However, BaAG2 exhibited moderate, but clearly detectable and recordable exo-hydrolysis of amylose, amylopectin and glycogen. The activity was the highest with amylopectin, and the lowest with amylose (Figure 7). From amylopectin $(5 \mathrm{~g} / \mathrm{L}), 0.1 \mathrm{~g} / \mathrm{L}$ of glucose was released by $24 \mathrm{~h}$, and $0.3 \mathrm{~g} / \mathrm{L}$ by $72 \mathrm{~h}$ of the reaction. In the case of ScMAL62, no hydrolysis of amylose was detected, and hydrolysis of glycogen and amylopectin became detectable only by $72 \mathrm{~h}$ of the reaction (Figure 7).

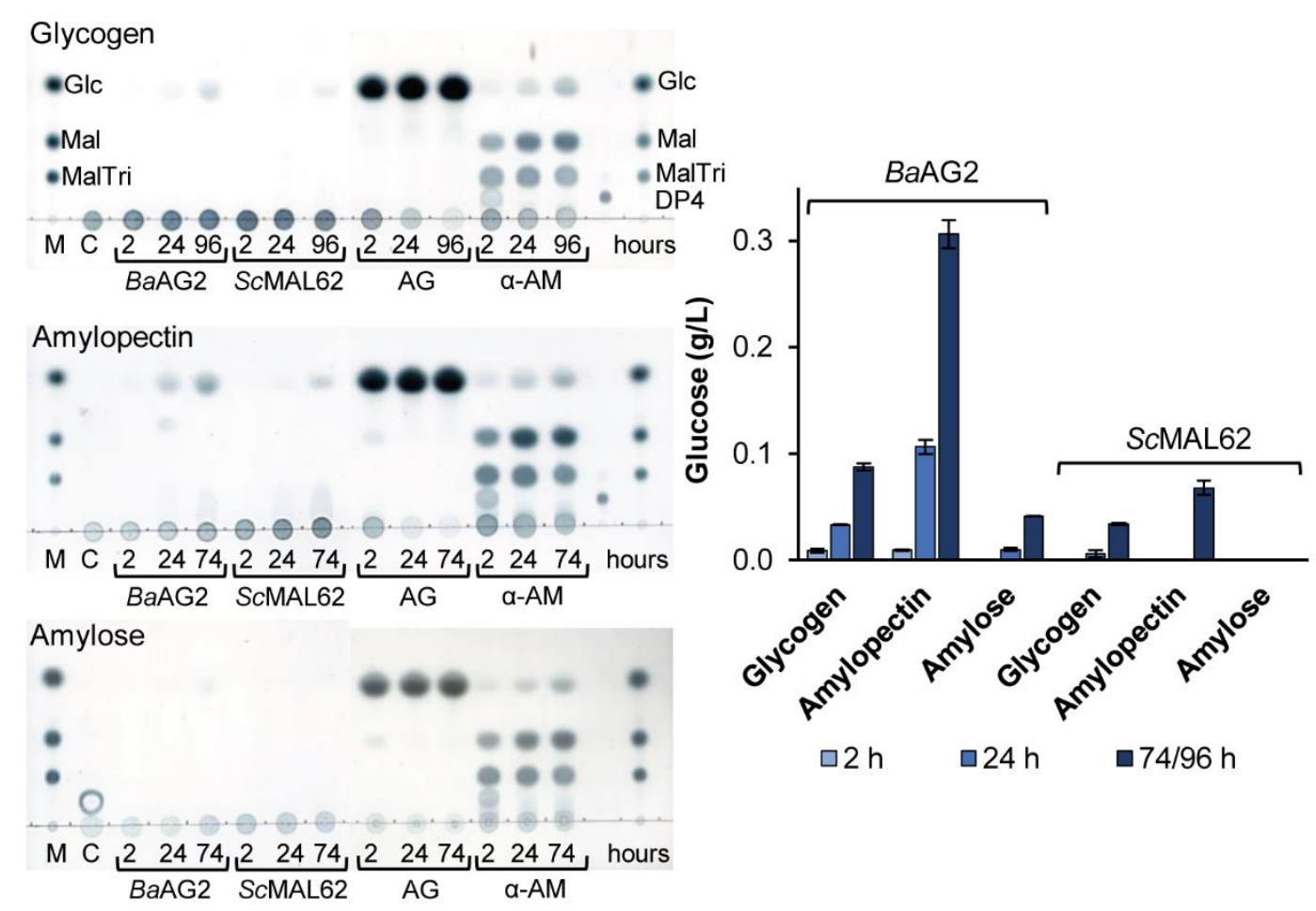

Figure 7. Hydrolysis of polysaccharides ( $5 \mathrm{~g} / \mathrm{L}$ ) by BaAG2, ScMAL62 and amyloglycosidase of $A$. niger (AG) and $\alpha$-amylase of $A$. oryzae ( $\alpha$-AM). Samples withdrawn at indicated time points were analyzed using TLC. Reaction mixtures were spotted on TLC plates alongside with reference sugars (M): Glc (30 mM glucose); Mal (10 mM maltose); MalTri (10 mM maltotriose); DP4 (10 mM maltotetraose). The same marker sugars were used in all assays but are marked only on TLC plate of glycogen degradation. C - control sample without the enzyme but containing $5 \mathrm{~g} / \mathrm{L}$ bovine serum albumin (BSA) incubated at the same conditions for 74/96 h. Glucose release was quantified enzymatically. See Materials and Methods, paragraphs 4.3 and 4.6 for details. SDs of two to three replicates are shown by error bars. 


\subsubsection{The Transglycosylation of Maltose}

Many $\alpha$-glucosidases can transglycosylate and produce short oligosaccharides, especially at high concentration of the substrate [17-21]. We assayed this possibility by incubating BaAG2 with 250 and $500 \mathrm{mM}$ maltose up to $72 \mathrm{~h}$ and analyzed the reaction products by HPLC. The maltase MAL62 of S. cerevisiae was used as a reference. Figure 8 and Table S3 show that already within $2 \mathrm{~h}$ at $250 \mathrm{mM}(85.6 \mathrm{~g} / \mathrm{L})$ maltose concentration, $B a A G 2$ produced maltotriose $(4.2 \mathrm{~g} / \mathrm{L})$ and panose, $\alpha$-D-Glc- $(1 \rightarrow 6)-\alpha$-D-Glc- $(1 \rightarrow 4)$-D-Glc $(1.6 \mathrm{~g} / \mathrm{L})$, in addition to a maltose hydrolysis product-glucose. By $72 \mathrm{~h}$ of reaction, the maltotriose content was decreased and panose content increased to $2.6 \mathrm{~g} / \mathrm{L}$ (Figure 8, Table S3). The ScMAL62 produced only maltotriose under the same conditions, and its amount was considerably lower than in the case of $B a A G 2$ - only $2.0 \mathrm{~g} / \mathrm{L}$ produced by $2 \mathrm{~h}$ of reaction (Figure 8, Table S3). Transglycosylation of maltose was enhanced at $500 \mathrm{mM}(171.2 \mathrm{~g} / \mathrm{L})$ concentration: up to $13.3 \mathrm{~g} / \mathrm{L}$ of maltotriose was produced by $2 \mathrm{~h}$ and $10.4 \mathrm{~g} / \mathrm{L}$ of panose by $72 \mathrm{~h}$ of reaction. Notably, a new transglycosylation product, isomaltose, emerged. It was produced by both enzymes, but its concentration was certainly higher in the case of $\mathrm{BaAG} 2$-its concentration in the 72-h reaction sample was $5.2 \mathrm{~g} / \mathrm{L}$ (Table S3). By $24 \mathrm{~h}$ of reaction with $500 \mathrm{mM}$ maltose, the amount of transglycosylation products was $12.6 \%$ of total sugars in the reaction mixture, while the respective value for the MAL62 protein was about three times less- $4.5 \%$ (see Table S3).
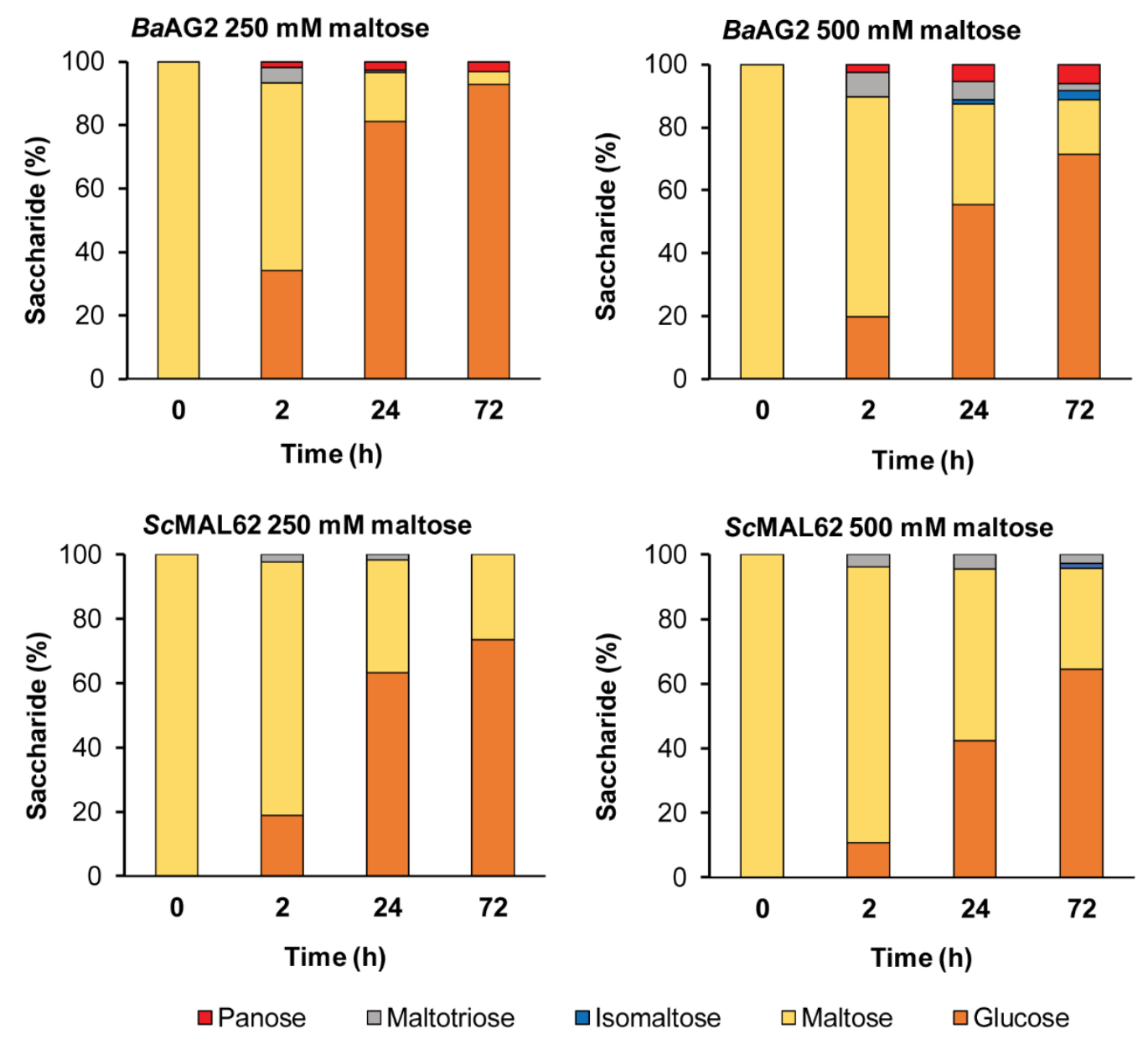

Figure 8. Transglycosylation of maltose by BaAG2 and ScMAL62. $20 \mu \mathrm{g} / \mathrm{mL}$ of the enzyme was reacted with $250 \mathrm{mM}$ or $500 \mathrm{mM}$ of maltose. Samples from the reaction mixtures were withdrawn at designated time points, heated to terminate the reaction and analyzed for sugar composition by HPLC as described in Materials and Methods, paragraphs 4.5. and 4.6. Total amount of detected saccharides at each time point was equalled to $100 \%$. Products were identified using glucose, maltose, isomaltose, maltotriose and panose as references. SDs of two to three HPLC measurements at each time point were up to $20 \%$. 
We tested panose hydrolysis by BaAG2 and conclude that it accumulated in transglycosylation reaction since it was not hydrolyzed by the enzyme even during extended ( $22 \mathrm{~h}$ ) reaction time (Figure S3). In contrast, maltotriose was hydrolysed by BaAG2 (Figure 5, Table 1), and due to that, its content decreased at prolonged transglycosylation reaction (Figure 8, Table S3).

\section{Discussion}

Utilization of $\alpha$-glucosidic sugars by maltases and isomaltases has earlier been thoroughly studied in S. cerevisiae because metabolism of these sugars is crucial in brewing and baking [22,48]. However, transport and intracellular hydrolysis of $\alpha$-glucosidic sugars have also been investigated in Ogataea polymorpha [25] and Schizosaccharomyces pombe [33,49]. A maltase has been characterized from C. albicans [41] and four maltase-isomaltases from Scheffersomyces stipitis [12]. Genes potentially encoding for either maltases, isomaltases or maltase-isomaltases were recently discovered in the genomes of many non-conventional yeasts [12]. Yeast species with deep phylogeny were expected to possess ancient-like $\alpha$-glucosidases [12]. Figure 9 shows the phylogram of selected yeast species and A. oryzae based on sequence analysis of D1/D2 domains of large subunit ribosomal RNA to illustrate the evolutionary relationships between the species. B. adeninivorans and Lipomyces starkeyi belong to basal group of Saccharomycotina [50]. Based on phylogenetic analysis of orthologous proteins [4], this group diverged from S. cerevisiae lineage 200 to 400 million, and from the CTG clade 200 million years ago. The basal group is considered very heterogeneous, its most studied member is Yarrowia lipolytica (not presented in Figure 9) and the most basal lineage to this group and all Saccharomycotina is Lipomyces starkeyi [50].

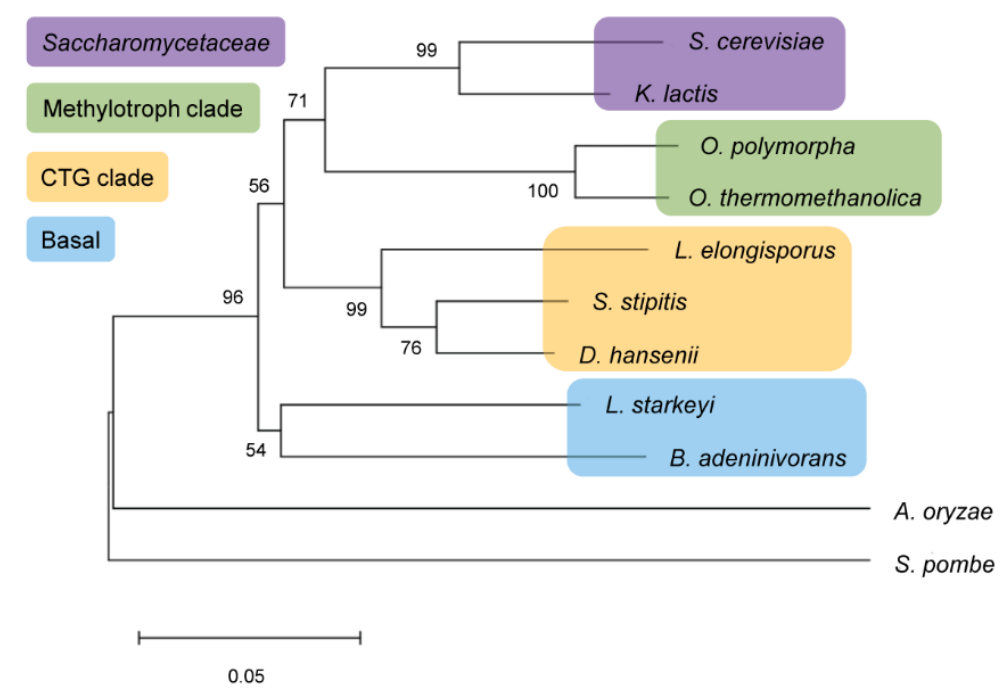

Figure 9. Phylogram based on analysis of D1/D2 domains of large subunit ribosomal RNA (rRNA) gene sequences of ten yeast species and of a filamentous fungus Aspergillus oryzae. The bootstrap values (1000 replicates) are shown at the nodes. The scale bar shows the number of base substitutions per site. The Saccharomycotina clades according to [50] are designated by background coloring.

On the phylogram (Figure 9), B. adeninivorans clusters with Lipomyces starkeyi. Genes for eight intracellular $\alpha$-glucosidases (five maltases and three isomaltases) were predicted in the genome of L. starkeyi. In the phylogram of $\alpha$-glucosidases from non-conventional yeasts, all eight Lipomyces enzymes clustered with those of $B$. adeninivorans [12]. However, these putative $\alpha$-glucosidases of L. starkeyi have not been cloned for protein expression and characterization. In Kelly et al. an extracellular $\alpha$-glucosidase from L. starkeyi was biochemically characterized [51]. Unfortunately, the sequence data of this protein is not available. The above-mentioned enzyme of L. starkeyi had equally high activity on maltose and isomaltose, but it also hydrolyzed maltotriose, isomaltotriose, panose, 
amylopectin and starch. Its activity with starch and amylopectin comprised 31 and $42 \%$ of that with maltose and isomaltose, and due to this feature, the authors considered it more similar to fungal rather than yeast enzymes [51]. Interestingly, this enzyme did not hydrolyze sucrose and had a quite low activity on $p$ NPG. Typically, yeast $\alpha$-glucosidases hydrolyze $p$ NPG more rapidly than maltose. or sucrose [16,24] (Table 1) whereas the opposite is true for maltases of bacteria and archaea [52-54].

Our study showed that $B a \mathrm{AG} 2$ is a maltase. $\mathrm{BaAG} 2$ efficiently hydrolyzed maltose and maltose-like sugars, but could not hydrolyze isomaltose, palatinose nor $\alpha-\mathrm{MG}$ that are specific substrates for yeast isomaltases (Figure 5, Table 1). Isomaltose, isomaltose-like sugars as well as acarbose and glucose competitively inhibited $p$ NPG hydrolysis by $B a A G 2$ and increased thermostability of the enzyme (Table 2; Figure 6). We also discovered a very strong inhibition of $B a A G 2$ by Tris with the $K_{i}$ of $70.5 \mu \mathrm{M}$ (Table 2). Tris also considerably increased thermostability of BaAG2 in a DSF assay (Figure 6). As thermostability of S. cerevisiae isomaltases was also elevated in the presence of Tris [55], it may bind to the active site of these enzymes. Literature mining revealed Tris as a competitive inhibitor of Bacillus brevis maltase with the $\mathrm{K}_{\mathrm{i}}$ of $14.5 \mathrm{mM}$ [56]. In a yeast Brettanomyces bruxellensis (former name $B r$. lambicus), both extra- and intracellular maltases were inhibited not only by acarbose $\left(\mathrm{K}_{\mathrm{i}}\right.$ values between 28.5 and $57 \mu \mathrm{M})$ but also by Tris $\left(\mathrm{K}_{\mathrm{i}}\right.$ values between 7.45 and $\left.15.7 \mathrm{mM}\right)$ [57]. Compared to Br. bruxellensis and Bacillus brevis maltases, BaAG2 was much more sensitive to Tris. The $\mathrm{pH}$ optimum of $B a \mathrm{AG} 2$ was in a moderate acidic region as in the case of other yeast maltases [23,24]. The temperature optimum for $\mathrm{BaAG} 2$ was between $40-50{ }^{\circ} \mathrm{C}$, with maximum activity $(530 \mathrm{U} / \mathrm{mg})$ achieved at $45^{\circ} \mathrm{C}$. Thermostability of the enzyme was not high-after keeping the enzyme at $45^{\circ} \mathrm{C}$ for $30 \mathrm{~min}$, the enzyme's activity dropped to $46 \%$ from the initial. Incubation for $30 \mathrm{~min}$ at $50^{\circ} \mathrm{C}$ totally inactivated the enzyme (Figure 4). According to literature data, thermolability has been reported for some other yeast $\alpha$-glucosidases. For example, the four isomaltases of $S$. cerevisiae had all low thermostability. Of those, the IMA1 was most stable, and IMA5 the least stable [55].

According to Hasegawa et al., the MalT protein of A. oryzae that has $51 \%$ of sequence identity to $B a A G 2$ (Table S2) exhibited $p$ NPG-hydrolyzing activity, its expression was induced when grown on maltose, and thereby the MalT was defined by the authors as a maltase [36]. To date no additional data on MalT protein is available. The intracellular maltase (MAL1) protein of Schizosaccharomyces pombe, with $43.2 \%$ of sequence identity to BaAG2 hydrolyzed $p$ NPG and maltose, but had also activity on soluble starch, and some activity on sucrose [33].

Intriguingly, BaAG2 had a detectable hydrolytic activity on MOS with DP up to 7, glycogen, amylose and amylopectin (Figure 7 and Table S4). We assume that the ability to hydrolyze MOS and to cleave polymeric $\alpha$-glucans, at least to some extent, may be characteristic to maltases of early-diverged yeasts. As BaAG2 is an intracellular enzyme, and this yeast possesses a secreted glucoamylase [9], the maltase $\mathrm{BaAG} 2$ has most probably no role in starch degradation. However, yeasts synthesize glycogen as a reserve polysaccharide [58]. Considering that BaAG2 had a remarkable activity on glycogen, the enzyme may contribute to glycogen catabolism in B. adeninivorans. We hypothesize that the ability to degrade malto-oligosaccharides and $\alpha$-glycosidic polysaccharides may be characteristic for the maltases of yeasts with deep phylogeny. Isolation and study of $\alpha$-glucosidases of the most basal lineages to Saccharomycotina, for example Lipomyces starkeyi, should verify the correctness of this hypothesis.

Several GHs of yeasts and filamentous fungi exhibit transglycosylating activity. For example, $\alpha$-glucosidase of a yeast X. dendrorhous (syn. Pfaffia rhodozyma) produced from maltose a large proportion of transglycosylation products with $\alpha-1,6$ linkage, among which panose was the most abundant [17]. It has been shown that the $S$. cerevisiae maltase also produced panose from maltose, yet transglycosylating activity of the Saccharomyces enzyme was more than three times smaller compared to the $X$. dendrorhous enzyme. Both enzymes also synthesized isomaltose and maltotriose, but the latter was rapidly used by the enzymes and was therefore not present among the final products [17]. We showed that maltotriose was produced from maltose also by BaAG2 (Figure 8, Table S3), but as it serves as a substrate for the enzyme (Table 1), it was eventually hydrolyzed. $\alpha$-Glucosidases of filamentous fungi 
have been suggested as feasible catalysts for transglycosylation. Thus, an Aspergillus enzyme with high transglycosylating activity was reported to produce panose and isomaltose from maltose $[18,59,60]$. When an $A$. nidulans $\alpha$-glucosidase with strong transglycosylating activity was reacted with $5 \mathrm{~g} / \mathrm{L}$ maltose during $6 \mathrm{~h}$, approximately $50 \%$ of maltose was converted to transglycosylation products, $60 \%$ of which was isomaltose [60]. Notably, in addition to maltotriose and panose, isomaltose was also detected among the transglycosylation products produced from maltose by BaAG2 (Figure 8, Table S3). Isomaltose synthesis from maltose was also confirmed for ScMAL62, even though the content of it was only minimal (Figure 8, Table S3).

\section{Materials and Methods}

\subsection{Yeast and Bacterial Strains, Cultivation of B. adeninivorans}

Blastobotrys (Arxula) adeninivorans LS3 (CBS 8244) was kindly provided by Assoc. Prof. V. Passoth (SLU, Uppsala, Sweden). The yeast strain was grown on solid YPD medium (20 g/L peptone, $20 \mathrm{~g} / \mathrm{L}$ glucose, $10 \mathrm{~g} / \mathrm{L}$ yeast extract, $20 \mathrm{~g} / \mathrm{L}$ agar) at $30^{\circ} \mathrm{C} 24 \mathrm{~h}$ for harvesting the cells for genomic DNA extraction. E. coli DH5 $\alpha$ (Thermo Fisher Scientific, Waltham, MA, USA) was used for DNA cloning and plasmid production. E. coli BL21 (DE3) [61] was used for heterologous expression of BaAG2. The ability of B. adeninivorans to grow on sugars was assayed as in [12]. Yeast cells grown overnight on BD Difco YNB medium (Thermo Fisher Scientific, Waltham, MA, USA) without amino acids containing $2 \mathrm{~g} / \mathrm{L}$ glucose were used as inoculum. The YNB medium was supplemented with $2 \mathrm{~g} / \mathrm{L}$ of a filter-sterilized sugar (glucose, maltose, maltotriose, isomaltose, maltulose, $\alpha$-methylglucoside, sucrose, raffinose, melibiose, turanose, palatinose, melezitose or trehalose). The cells were incubated on Greiner 96-well flat-bottom transparent polystyrene microplates (Greiner Bio-One, Frickenhausen, Germany) in $200 \mu \mathrm{l}$ under agitation for $24 \mathrm{~h}$ at $37^{\circ} \mathrm{C}$. Optical density of the culture at $600 \mathrm{~nm}$ was measured against inoculated medium without sugar at the beginning and end of the experiment using an Infinite M200 PRO microplate reader (Tecan Group Ltd., Männedorf, Switzerland) equipped with Tecan i-control v. 1.7 software from the same provider. Two independent experiments with two parallel measurements were conducted.

\subsection{Cloning, Heterologous Expression and Protein Purification}

Genomic DNA of B. adeninivorans was extracted using PowerMax Soil DNA Isolation Kit (MoBio Laboratories, Carlsbad, CA, USA) and the standard protocol by manufacturer. The oligonucleotide primers Ba20130g_PURICter_Fw (5' TAACTTTAAGAAGGAGATATACAT ATGGTTCTAGGATTTTTCAAAAAG $3^{\prime}$ ) and Ba20130g_PURICter_Rev (5' GCTATTAATGATGATG ATGATGATGGATTTCATAGATGACTGCCTCCA $3^{\prime}$ ), designed according to the gene sequence of rna_ARAD1D20130g, were applied to amplify a $1789 \mathrm{bp}$ fragment that represented the coding sequence of $B a A G 2$ [12]. In the primers, the nucleotides annealing with the pURI3Cter vector [62] are shown in bold and those annealing with the $B a A G 2$ gene sequence are shown in italics. The ATG start codon and the stop codon are underlined in the primer sequences. Recombinant $P f u$ polymerase (Thermo Fisher Scientific, Waltham, MA, USA) and $2.6 \mathrm{ng}$ per $\mu \mathrm{L}$ of reaction mixture of genomic DNA were used in amplification. The PCR product was cloned into a pJET vector from CloneJET PCR Cloning Kit (Thermo Fisher Scientific, Waltham, MA, USA), yielding pJET-BaAG2. To produce the BaAG2 protein with a C-terminal $\mathrm{His}_{6}$-tag, an expression plasmid pURI3-AG2Cter was constructed by cloning the $B a A G 2$ gene into pURI3-Cter vector similarly as in [63]. Insertion of the $B a A G 2$ gene into the vector was confirmed by DNA sequencing. The cloning procedure was conducted with recombinant $P f u$ polymerase (Thermo Fisher Scientific, Waltham, MA, USA). DNA Clean \& Concentrator-5 Kit (Zymo Research, Irvine, CA, USA) was used for purification and concentration of PCR products. Plasmid DNA was purified with FavorPrep Plasmid Extraction Mini Kit (Favorgen Biotech Corp., Ping-Tung, Taiwan). The MAL62-containing plasmid pURI-ScMAL62Cter [12] was used to produce the S. cerevisiae maltase protein that was analyzed as a reference. 
The pURI3-BaAG2Cter and pURI-ScMAL62Cter containing the BaAG2 gene or MAL62 gene, respectively, were electroporated into E. coli BL21 (DE3) for heterologous expression. A simplified autoinduction medium as in [64] was used for protein overproduction: the LB-based medium ( $20 \mathrm{~g} / \mathrm{L}$ tryptone, $5 \mathrm{~g} / \mathrm{L}$ yeast extract, $5 \mathrm{~g} / \mathrm{L} \mathrm{NaCl}$ ) was supplemented with $25 \mathrm{mM}$ phosphate buffer $\left(\mathrm{Na}_{2} \mathrm{HPO}_{4} / \mathrm{KH}_{2} \mathrm{PO}_{4} ; \mathrm{pH} 7.2\right)$ and $3 \mathrm{~g} / \mathrm{L}$ glycerol to which filter-sterilized $0.25 \mathrm{~g} / \mathrm{L}$ glucose and $1 \mathrm{~g} / \mathrm{L}$ lactose were added. Medium for transformant selection contained ampicillin (Amp, $150 \mathrm{mg} / \mathrm{L}$ ) for plasmid preservation. Bacterial cells were grown overnight in LB-Amp medium at $37^{\circ} \mathrm{C}$ and diluted 100 times in autoinduction medium. At first, the cultures were incubated for $2 \mathrm{~h}$ at $37^{\circ} \mathrm{C}$ followed by 20 -h incubation at $22^{\circ} \mathrm{C}$. The cells were harvested by centrifugation $(2400 \times g, 10 \mathrm{~min})$ at $4{ }^{\circ} \mathrm{C}$ and stored at $-20^{\circ} \mathrm{C}$ until further use. Cells were disrupted by sonication with Ultrasonic Homogenizer (Cole-Parmer Instrument Company, Vernon Hills, IL, USA) in 100 mM K-phosphate buffer (pH 6.5) with the cOmplete, EDTA-free Protease Inhibitor Cocktail (Roche Diagnostics, Mannheim, Germany), and centrifuged $30 \mathrm{~min}$ at $2400 \times g$ at $4{ }^{\circ} \mathrm{C}$. The resulting supernatants were syringe-filtered (pore size $0.45 \mu \mathrm{m}$ ) and loaded onto an IMAC HisTrap FF column coupled with an ÄKTAprime plus chromatography system (GE Healthcare, Uppsala, Sweden). Further purification steps were conducted as described in [63]. Proteins were quantified by measuring the absorbance at $280 \mathrm{~nm}$. The respective extinction coefficients of BaAG2 [133,855 1/(M × cm)] and ScMAL62 [148,990 1/(M × cm)] were computed at ExPASy Proteomics Server (http://expasy.org). Purified proteins were maintained in 100 mM K-phosphate buffer ( $\mathrm{pH} 6.5)$ at $4{ }^{\circ} \mathrm{C}$.

\subsection{Determination of Substrate Specificity, Kinetic Parameters and Inhibition}

Hydrolysis of $p$ NPG was assayed as in $[16,40]$ according to the release of $p$-nitrophenol. $100 \mathrm{mM}$ K-phosphate buffer ( $\mathrm{pH}$ 6.5) was used and reactions were conducted at $30{ }^{\circ} \mathrm{C}$ if not stated otherwise. The purified enzyme was unstable if diluted therefore $5 \mathrm{~g} / \mathrm{L}$ bovine serum albumin (BSA) was added to the dilution buffer as a protein stabilizer to retain its full catalytic activity. For preliminary assay of substrate specificity of $B a A G 2$, the enzyme was reacted with $100 \mathrm{mM}$ concentration of various potential substrates: maltose, sucrose, maltotriose, isomaltose, melezitose, maltulose, turanose, palatinose or $\alpha$-MG. At fixed time points, aliquots were withdrawn, combined with three volumes of $200 \mathrm{mM}$ Tris buffer ( $\mathrm{pH} 8.3$ ) and subsequently heated at $96^{\circ} \mathrm{C}$ for $5 \mathrm{~min}$ to stop the reaction. The content of the released glucose was determined spectrophotometrically as in $[16,47]$. The activities ( $\mu$ moles of glucose released per minute per $\mathrm{mg}$ of protein; $\mathrm{U} / \mathrm{mg}$ ) were calculated from initial velocities of the reaction. For kinetic analysis, initial rates of $p$-nitrophenol or glucose release from substrates were measured at four to seven concentrations ranging from $0.1-3.0 \mathrm{mM}$ for $p$ NPG and $2.5-250 \mathrm{mM}$ for diand trisaccharides. At least three independent measurements for each substrate and concentration were made. BaAG2 content in reaction mixtures ranged from 0.02 to $3.5 \mu \mathrm{g} / \mathrm{mL}$. The initial velocity data analysis with enzyme kinetics module of the SigmaPlot (Systat Software, San Jose, CA, USA) yielded kinetic parameters $\left(\mathrm{K}_{\mathrm{m}}, \mathrm{V}_{\max }\right)$ for the enzyme. $k_{\text {cat }}$ and $k_{\mathrm{cat}} / \mathrm{K}_{\mathrm{m}}$ were calculated from these data. The theoretical $\mathrm{M}_{\mathrm{w}}$ value of 67,901 Da for the $k_{\text {cat }}$ calculation was computed in ExPASy Proteomics Server (http://expasy.org).

Inhibition of $B a A G 2$ was studied by incubating a suitable amount of enzyme $(0.035-0.13 \mu \mathrm{g} / \mathrm{mL})$ with $0.2-2.0 \mathrm{mM} p \mathrm{NPG}$ in the presence of following potential inhibitors: $5 \mu \mathrm{M}$ acarbose, $0.1 \mathrm{mM}$ Tris, $5 \mathrm{mM}$ palatinose, $10 \mathrm{mM}$ isomaltose, $10 \mathrm{mM}$ glucose, $100 \mathrm{mM} \alpha$-methylglucoside, $100 \mathrm{mM}$ trehalose or $400 \mathrm{mM}$ fructose. The $\mathrm{K}_{\mathrm{i}}$ values were calculated using enzyme kinetics module of the SigmaPlot (Systat Software, San Jose, CA, USA).

Differential scanning fluorimetry (DSF) was used to evaluate the thermostability of BaAG2 in the presence and absence of ligands. The concentration of $B a A G 2$ was used with $2 \mu \mathrm{M}$ and for ligands: $100 \mathrm{mM}$ fructose, $50 \mathrm{mM}$ palatinose, $50 \mathrm{mM}$ glucose, $5 \mathrm{mM}$ Tris and $5 \mathrm{mM}$ acarbose. The reaction was conducted in $50 \mathrm{mM}$ 4-(2-hydroxyethyl)-1-piperazineethanesulfonic acid) (HEPES) buffer ( $\mathrm{pH} 7.0$ ) with $150 \mathrm{mM} \mathrm{NaCl}$. The experiment was based on $[16,47,65]$ with above-mentioned modifications. At least two independent experiments were performed with two technical replicates. 
Degradation of glucose polymers, i.e., amylopectin-free amylose from potato, amylopectin from potato, glycogen from oysters and dextrans of $\mathrm{M}_{\mathrm{w}} 20 \mathrm{kDa}$ and $110 \mathrm{kDa}$, was assayed in K-phosphate buffer $(100 \mathrm{mM}, \mathrm{pH}$ 6.5) containing $0.2 \mathrm{~g} / \mathrm{L}$ Na-azide. Polysaccharide concentration in the reaction mixture was $5 \mathrm{~g} / \mathrm{L}$, and $20 \mu \mathrm{g} / \mathrm{mL}$ of the enzyme was used. At desired time points $(2 \mathrm{~h}, 24 \mathrm{~h}, 74 / 96 \mathrm{~h})$ aliquots were withdrawn and heated to stop the reaction. A negative control containing $20 \mu \mathrm{g} / \mathrm{mL}$ BSA instead of the enzyme was incubated alongside. Concentration of released glucose was measured as described above and $3 \mu \mathrm{l}$ of the samples were analysed on TLC. Maltase from S. cerevisiae (ScMAL62), amyloglycosidase from Aspergillus niger (Sigma-Aldrich, Merck, Darmstadt, Germany) and $\alpha$-amylase from Aspergillus oryzae (Sigma-Aldrich, Merck, Darmstadt, Germany) were reacted with tested glucose polymers for comparison.

To assay the hydrolysis of malto-oligosaccharides (DP 4-7), panose and melezitose by BaAG2 and ScMAL62, $50 \mathrm{mM}$ of the sugar was reacted with $2.6 \mu \mathrm{g} / \mathrm{mL}$ of the enzyme in K-phosphate buffer ( $100 \mathrm{mM}, \mathrm{pH} 6.5$ ) containing $0.1 \mathrm{~g} / \mathrm{L}$ of Na-azide and samples were withdrawn at fixed time points. $20 \mathrm{mM}$ isomelezitose (transglycosylation product from sucrose of Ogatae polymorpha MAL1) was also tested as a potential substrate. The reaction samples were analyzed using TLC.

\subsection{Determination of $\mathrm{pH}$ and Temperature Optima, Evaluation of Thermostability}

Initial velocity of $1 \mathrm{mM} p \mathrm{NPG}$ hydrolysis by $\mathrm{BaAG} 2$ was measured at $30{ }^{\circ} \mathrm{C}$ in BSA-supplemented buffers of varied $\mathrm{pH}$ (from 3.8 to 8.5) using McIlvaine's buffer (Na-phosphate/citrate buffer) [66] and $100 \mathrm{mM} \mathrm{K}$-phosphate buffer to cover respective $\mathrm{pH}$-interval, and data were plotted against the $\mathrm{pH}$ to determine the $\mathrm{pH}$ optimum. Hydrolysis of $1 \mathrm{mM} p \mathrm{NPG}$ was measured at varied temperatures from 20 to $65{ }^{\circ} \mathrm{C}$. Initial velocity data were plotted against the temperature to reveal the temperature optimum. For thermostability determination, BaAG2 was incubated in $100 \mathrm{mM} \mathrm{K}$-phosphate buffer ( $\mathrm{pH}$ 6.5) buffer containing $5 \mathrm{~g} / \mathrm{L} \mathrm{BSA}$ for $30 \mathrm{~min}$ at temperatures 10, 20, 30, 37, 45 and $50{ }^{\circ} \mathrm{C}$. After cooling the samples on ice, residual activity of the enzyme was determined according to the hydrolysis of $1 \mathrm{mM} p$ NPG at $30^{\circ} \mathrm{C}$. Every temperature point was assayed in triplicate. The activity measured after incubation at $10{ }^{\circ} \mathrm{C}$ was taken as $100 \%$.

\subsection{Study of Transglycosylation}

$20 \mu \mathrm{g} / \mathrm{mL}$ of the enzyme (BaAG2 or ScMAL62) was incubated in $100 \mathrm{mM} \mathrm{K}$-phosphate buffer (pH 6.5) with $0.2 \mathrm{~g} / \mathrm{L} \mathrm{Na-azide} \mathrm{and} 250 \mathrm{mM}$ or $500 \mathrm{mM}$ maltose at $30^{\circ} \mathrm{C}$ up to $72 \mathrm{~h}$. The samples with $\mathrm{BaAG} 2$ also contained $5 \mathrm{~g} / \mathrm{L}$ BSA. Samples were withdrawn at fixed intervals, heated at $95^{\circ} \mathrm{C}$ to stop the reaction and analysed on TLC and by HPLC.

\subsection{Chromatography of Substrates and Reaction Products}

To visualize hydrolysis and polymerization products, the TLC analysis was conducted as in [16] on Silica Gel $60 \mathrm{~F}_{254}$ plates with concentrating zone (Merck, Darmstadt, Germany). $0.5 \mu \mathrm{l}$ of the stopped reaction mixture were spotted onto the plate and sugars were separated with two runs in chloroform:acetic acid:water (6:7:1, v:v:v) [67]. For the analysis of products of polysaccharide degradation, $3 \mu \mathrm{l}$ of the reaction mixtures were spotted. Sugars were visualized by immersion of the plates in aniline-diphenylamine reagent and subsequent heating of the dried plates at $100{ }^{\circ} \mathrm{C}$ [68].

HPLC analysis was performed similarly as in [65]. Glucose and fructose were used to calibrate the column. Fructose, maltose, sucrose, isomaltose, palatinose, turanose, maltotriose, panose and melezitose were used as reference sugars.

\subsection{Alignment of RNA and Protein Sequences and Construction of the Phylogram}

Gene sequences from domains 1 and 2 (D1/D2) of large subunit ribosomal RNA were aligned to build a neighbor-joining phylogenetic tree [69] of yeasts using MEGA v. 7.0 [70]. The maximum composite likelihood model [71] with 1000 bootstrap replicates was applied. Protein sequences were aligned using Clustal Omega [72] to calculate identity values of the proteins. 
4.8. Extraction of Amino Acid Signature from the Alignments and Visualization of Respective Positions on the three-dimensional (3D) Model of S. cerevisiae Isomaltase IMA1

Protein sequences of S. cerevisiae maltase MAL62 (UniProtKB: P07265), S. cerevisiae isomaltase IMA1 (UniProtKB: YGR287C), O. polymorpha maltase-isomaltase MAL1 (UniProtKB: Q9P8G8) and B. adeninivorans AG2 were aligned using Clustal Omega [72] and amino acids corresponding to IMA1 signature positions determining the substrate specificity $[12,15]$ were extracted from the alignment. The S. cerevisiae IMA1 structure in complex with isomaltose (PDB: 3AXH) [29] was visualized with PyMol [30] and amino acid signature was designated on the structure.

\section{Conclusions}

According to the literature data, a non-conventional yeast Blastobotrys (Arxula) adeninivorans belonging to the basal group of Saccharomycotina diverged in the evolution of yeasts hundreds of millions of years before Saccharomyces and can be considered as a yeast species with deep phylogeny. The genome of $B$. adeninivorans encodes two putative $\alpha$-glucosidases. In current work, one of them, BaAG2, was produced in E. coli and characterized in detail. BaAG2 was proven to be a maltase-hydrolysing $\alpha-1,4$ and $\alpha-1,3$ but not $\alpha-1,6$ linkages in glucose-containing substrates. Interestingly, BaAG2 was strongly and competitively inhibited not only by acarbose, a diabetes drug and a well-known inhibitor of $\alpha$-glucosidases, but also by Tris. Importantly, at high maltose concentrations, BaAG2 exhibited transglycosylating ability producing potentially prebiotic di- and trisaccharides: isomaltose, panose and maltotriose. Thus, BaAG2 may have a biotechnological value. In contrast to yeast maltases, BaAG2 showed exo-hydrolytic activity on starch, amylose, amylopectin and glycogen. S. cerevisiae maltase MAL62 assayed for comparison had only minimal ability towards these polymers and its transglycosylating activity was much lower.

Supplementary Materials: Supplementary file can be found at http://www.mdpi.com/1422-0067/21/1/297/s1.

Author Contributions: Conceptualization, T.A. and T.V.; Methodology, T.V., K.E., A.M., K.P. and K.V.; Validation, T.V., K.E. and T.A.; Formal Analysis, T.V., A.M., K.P. and K.E.; Investigation, T.V. A.M., K.V., K.P., K.E. and T.A.; Resources, T.A. and T.V.; Writing-original draft preparation, T.A. and T.V.; Writing-review and editing, T.A., T.V., K.E. and K.P.; Visualization, T.V., K.E., A.M., K.P. and T.A.; supervision, T.A. and T.V.; funding acquisition, T.A and T.V. All authors have read and agreed to the published version of the manuscript.

Funding: This work was funded by the Estonian Research Council (grant number PUT1050) to T.A. The article processing charge was covered by University of Tartu Feasibility Fund grant PLTMRARENG13 to T.V.

Acknowledgments: We thank V. Passoth (SLU, Uppsala, Sweden) for providing the B. adeninivorans strain, B. Svensson (DTU, Kongens Lyngby, Denmark) for providing amylose and amylopectin and H. Vija (NICPB, Tallinn, Estonia) for the services in sugar quantification.

Conflicts of Interest: The authors declare no conflict of interest. 


\section{Abbreviations}

$\begin{array}{ll}\text { BaAG2 } & \alpha \text {-glucosidase } 2 \text { of Blastobotrys adeninivorans } \\ \text { BSA } & \text { bovine serum albumin } \\ \text { DP } & \text { degree of polymerization } \\ \text { DSF } & \text { differential scanning fluorimetry } \\ \text { GH } & \text { glycoside hydrolase } \\ \text { MOS } & \text { malto-oligosaccharides } \\ \alpha-M G & \alpha \text {-methylglucoside } \\ \text { PDB } & \text { RCSB Protein Data Bank } \\ p \text { NPG } & \text { p-nitrophenyl- } \alpha \text {-D-glucopyranoside } \\ \text { OD } & \text { optical density } \\ \text { rRNA } & \text { ribosomal RNA } \\ \text { ScMAL62 } & \text { maltase MAL62 of Saccharomyces cerevisiae } \\ \text { SD } & \text { standard deviation } \\ \text { TLC } & \text { thin layer chromatography } \\ T_{m} & \text { melting temperature } \\ \text { Tris } & \text { tris(hydroxymethyl)aminomethane } \\ \text { YNB } & \text { Yeast Nitrogen Base }\end{array}$

\section{References}

1. Kurtzman, C.P.; Robnett, C.J. Multigene phylogenetic analysis of the Trichomonascus, Wickerhamiella and Zygoascus yeast clades, and the proposal of Sugiyamaella gen. nov. and 14 new species combinations. FEMS Yeast Res. 2007, 7, 141-151. [CrossRef] [PubMed]

2. Kunze, G.; Gaillardin, C.; Czernicka, M.; Durrens, P.; Martin, T.; Böer, E.; Gabaldón, T.; Cruz, J.A.; Talla, E.; Marck, C.; et al. The complete genome of Blastobotrys (Arxula) adeninivorans LS3-A yeast of biotechnological interest. Biotechnol. Biofuels 2014, 7, 66. [CrossRef]

3. Shen, X.-X.; Zhou, X.; Kominek, J.; Kurtzman, C.P.; Hittinger, C.T.; Rokas, A. Reconstructing the backbone of the Saccharomycotina yeast phylogeny using genome-scale data. G3 Genes Genomes Genet. 2016, 6, 3927-3939. [CrossRef] [PubMed]

4. Correia, K.; Yu, S.M.; Mahadevan, R. AYbRAH: A curated ortholog database for yeasts and fungi spanning 600 million years of evolution. Database 2019, 2019, baz022. [CrossRef] [PubMed]

5. Hedges, S.B.; Marin, J.; Suleski, M.; Paymer, M.; Kumar, S. Tree of life reveals clock-like speciation and diversification. Mol. Biol. Evol. 2015, 32, 835-845. [CrossRef] [PubMed]

6. Thomas, S.; Sanya, D.R.A.; Fouchard, F.; Nguyen, H.V.; Kunze, G.; Neuvéglise, C.; Crutz-Le Coq, A.M. Blastobotrys adeninivorans and $B$. raffinosifermentans, two sibling yeast species which accumulate lipids at elevated temperatures and from diverse sugars. Biotechnol. Biofuels 2019, 12, 154. [CrossRef] [PubMed]

7. Malak, A.; Baronian, K.; Kunze, G. Blastobotrys (Arxula) adeninivorans: A promising alternative yeast for biotechnology and basic research. Yeast 2016, 33, 535-547. [CrossRef]

8. Kasprzak, J.; Rauter, M.; Riechen, J.; Worch, S.; Baronian, K.; Bode, R.; Schauer, F.; Kunze, G. Characterization of an Arxula adeninivorans alcohol dehydrogenase involved in the metabolism of ethanol and 1-butanol. FEMS Yeast Res. 2016, 16, fow018. [CrossRef]

9. Bui, D.M.; Kunze, I.; Förster, S.; Wartmann, T.; Horstmann, C.; Manteuffel, R.; Kunze, G. Cloning and expression of an Arxula adeninivorans glucoamylase gene in Saccharomyces cerevisiae. Appl. Microbiol. Biotechnol. 1996, 44, 610-619. [CrossRef]

10. Böer, E.; Wartmann, T.; Luther, B.; Manteuffel, R.; Bode, R.; Gellissen, G.; Kunze, G. Characterization of the AINV gene and the encoded invertase from the dimorphic yeast Arxula adeninivorans. Antonie Van Leeuwenhoek 2004, 86, 121-134. [CrossRef]

11. Bao, M.; Niu, C.; Xu, X.; Zheng, F.; Liu, C.; Wang, J.; Li, Q. Identification, soluble expression, and characterization of a novel endo-inulinase from Lipomyces starkeyi NRRL Y-11557. Int. J. Biol. Macromol. 2019, 137, 537-544. [CrossRef] [PubMed]

12. Viigand, K.; Põšnograjeva, K.; Visnapuu, T.; Alamäe, T. Genome mining of non-conventional yeasts: Search and analysis of MAL clusters and proteins. Genes 2018, 9, 354. [CrossRef] [PubMed] 
13. Gabriško, M. Evolutionary history of eukaryotic $\alpha$-glucosidases from the $\alpha$-amylase family. J. Mol. Evol. 2013, 76, 129-145. [CrossRef] [PubMed]

14. Janeček, Š.; Gabriško, M. Remarkable evolutionary relatedness among the enzymes and proteins from the

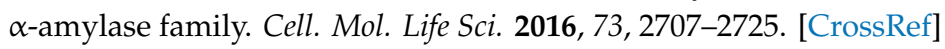

15. Voordeckers, K.; Brown, C.A.; Vanneste, K.; van der Zande, E.; Voet, A.; Maere, S.; Verstrepen, K.J. Reconstruction of ancestral metabolic enzymes reveals molecular mechanisms underlying evolutionary innovation through gene duplication. PLoS Biol. 2012, 10, e1001446. [CrossRef]

16. Viigand, K.; Visnapuu, T.; Mardo, K.; Aasamets, A.; Alamäe, T. Maltase protein of Ogataea (Hansenula) polymorpha is a counterpart to the resurrected ancestor protein ancMALS of yeast maltases and isomaltases. Yeast 2016, 33, 415-432. [CrossRef]

17. Fernández-Arrojo, L.; Marín, D.; Gómez De Segura, A.; Linde, D.; Alcalde, M.; Gutiérrez-Alonso, P.; Ghazi, I.; Plou, F.J.J.; Fernández-Lobato, M.; Ballesteros, A. Transformation of maltose into prebiotic isomaltooligosaccharides by a novel $\alpha$-glucosidase from Xantophyllomyces dendrorhous. Process Biochem. 2007, 42, 1530-1536. [CrossRef]

18. Mangas-Sánchez, J.; Adlercreutz, P. Enzymatic preparation of oligosaccharides by transglycosylation: A comparative study of glucosidases. J. Mol. Catal. B Enzym. 2015, 122, 51-55. [CrossRef]

19. Casa-Villegas, M.; Marín-Navarro, J.; Polaina, J. Amylases and related glycoside hydrolases with transglycosylation activity used for the production of isomaltooligosaccharides. Amylase 2018, 2, 17-29. [CrossRef]

20. Gutiérrez-Alonso, P.; Gimeno-Pérez, M.; Ramírez-Escudero, M.; Plou, F.J.; Sanz-Aparicio, J.; Fernández-Lobato, M. Molecular characterization and heterologous expression of a Xanthophyllomyces dendrorhous $\alpha$-glucosidase with potential for prebiotics production. Appl. Microbiol. Biotechnol. 2016, 100, 3125-3135. [CrossRef]

21. Chiba, S.; Murata, M.; Matsusaka, K.; Shimomura, T. A new trisaccharide, 6F- $\alpha$-D-glucosyl-sucrose, synthesized by transglucosylation reaction of brewer's yeast $\alpha$-glucosidase. Agric. Biol. Chem. 1979, 43, 775-779. [CrossRef]

22. Stewart, G. Saccharomyces species in the production of beer. Beverages 2016, 2, 34. [CrossRef]

23. Needleman, R.B.; Marmur, J.; Federoff, H.J.; Eccleshall, T.R.; Buchferer, B. Purification and characterization of an $\alpha$-glucosidase from Saccharomyces carlsbergensis. Biochemistry 1978, 17, 4657-4661. [CrossRef] [PubMed]

24. Krakenaĭte, R.P.; Glemzha, A.A. Some properties of two forms of alpha-glucosidase from Saccharomyces cerevisiae-II. Biokhimiia 1983, 48, 62-68.

25. Alamäe, T.; Viigand, K.; Põšnograjeva, K. Utilization of $\alpha$-glucosidic disaccharides by Ogataea (Hansenula) polymorpha: Genes, proteins, and regulation. In Non-Conventional Yeasts: From Basic Research to Application; Sibirny, A., Ed.; Springer International Publishing: Cham, Switzerland, 2019; pp. 1-22.

26. Grigoriev, I.V.; Nikitin, R.; Haridas, S.; Kuo, A.; Ohm, R.; Otillar, R.; Riley, R.; Salamov, A.; Zhao, X.; Korzeniewski, F.; et al. MycoCosm portal: Gearing up for 1000 fungal genomes. Nucleic Acids Res. 2014, 42, D699-D704. [CrossRef]

27. Yamamoto, K.; Miyake, H.; Kusunoki, M.; Osaki, S. Crystal structures of isomaltase from Saccharomyces cerevisiae and in complex with its competitive inhibitor maltose. FEBS J. 2010, 277, 4205-4214. [CrossRef]

28. Yamamoto, K.; Nakayama, A.; Yamamoto, Y.; Tabata, S. Val216 decides the substrate specificity of $\alpha$-glucosidase in Saccharomyces cerevisiae. Eur. J. Biochem. 2004, 271, 3414-3420. [CrossRef]

29. Yamamoto, K.; Miyake, H.; Kusunoki, M.; Osaki, S. Steric hindrance by 2 amino acid residues determines the substrate specificity of isomaltase from Saccharomyces cerevisiae. J. Biosci. Bioeng. 2011, 112, 545-550. [CrossRef]

30. Schrödinger, L.L.C. The \{PyMOL\} Molecular Graphics System, Version 1.8.6.0. 2015. Available online: https://pymol.org/2/ (accessed on 19 May 2017).

31. Janeček, Š.; Svensson, B.; MacGregor, E.A. A remote but significant sequence homology between glycoside hydrolase clan GH-H and family GH31. FEBS Lett. 2007, 581, 1261-1268. [CrossRef]

32. Uitdehaag, J.C.M.; Mosi, R.; Kalk, K.H.; Van der Veen, B.A.; Dijkhuizen, L.; Withers, S.G.; Dijkstra, B.W. $\mathrm{X}$-ray structures along the reaction pathway of cyclodextrin glycosyltransferase elucidate catalysis in the $\alpha$-amylase family. Nat. Struct. Biol. 1999, 6, 432-436. [CrossRef]

33. Chi, Z.; Ni, X.; Yao, S. Cloning and overexpression of a maltase gene from Schizosaccharomyces pombe in Escherichia coli and characterization of the recombinant maltase. Mycol. Res. 2008, 112, 983-989. [CrossRef] [PubMed] 
34. Tsujimoto, Y.; Tanaka, H.; Takemura, R.; Yokogawa, T.; Shimonaka, A.; Matsui, H.; Kashiwabara, S.I.; Watanabe, K.; Suzuki, Y. Molecular determinants of substrate recognition in thermostable $\alpha$-glucosidases belonging to glycoside hydrolase family 13. J. Biochem. 2007, 142, 87-93. [CrossRef] [PubMed]

35. Ojima, T.; Saburi, W.; Yamamoto, T.; Kudo, T. Characterization of Halomonas sp. strain H11 $\alpha$-glucosidase activated by monovalent cations and its application for efficient synthesis of $\alpha$-D-glucosylglycerol. Appl. Environ. Microbiol. 2012, 78, 1836-1845. [CrossRef] [PubMed]

36. Hasegawa, S.; Takizawa, M.; Suyama, H.; Shintani, T.; Gomi, K. Characterization and expression analysis of a maltose-utilizing (MAL) cluster in Aspergillus oryzae. Fungal Genet. Biol. 2010, 47, 1-9. [CrossRef] [PubMed]

37. CBS Database. Available online: http://www.wi.knaw.nl/Collections/DefaultInfo.aspx?Page=Home (accessed on 27 November 2019).

38. Teste, M.A.; Marie François, J.; Parrou, J.L. Characterization of a new multigene family encoding isomaltases in the yeast Saccharomyces cerevisiae, the IMA family. J. Biol. Chem. 2010, 285, 26815-26824. [CrossRef]

39. Almagro Armenteros, J.J.; Tsirigos, K.D.; Sønderby, C.K.; Petersen, T.N.; Winther, O.; Brunak, S.; von Heijne, G.; Nielsen, H. SignalP 5.0 improves signal peptide predictions using deep neural networks. Nat. Biotechnol. 2019, 37, 420-423. [CrossRef]

40. Liiv, L.; Pärn, P.; Alamäe, T. Cloning of maltase gene from a methylotrophic yeast, Hansenula polymorpha. Gene 2001, 265, 77-85. [CrossRef]

41. Geber, A.; Williamson, P.R.; Rex, J.H.; Sweeney, E.C.; Bennett, J.E. Cloning and characterization of a Candida albicans maltase gene involved in sucrose utilization. J. Bacteriol. 1992, 174, 6992-6996. [CrossRef]

42. Alamäe, T.; Liiv, L. Glucose repression of maltase and methanol-oxidizing enzymes in the methylotrophic yeast Hansenula polymorpha: Isolation and study of regulatory mutants. Folia Microbiol. 1998, 43, 443-452. [CrossRef]

43. Marín, D.; Linde, D.; Lobato, M.F. Purification and biochemical characterization of an $\alpha$-glucosidase from Xanthophyllomyces dendrorhous. Yeast 2006, 23, 117-125. [CrossRef]

44. da Silva, T.M.; Michelin, M.; de Lima Damásio, A.R.; Maller, A.; Almeida, F.B.D.R.; Ruller, R.; Ward, R.J.; Rosa, J.C.; Jorge, J.A.; Terenzi, H.F.; et al. Purification and biochemical characterization of a novel $\alpha$-glucosidase from Aspergillus niveus. Antonie Van Leeuwenhoek 2009, 96, 569-578. [CrossRef] [PubMed]

45. Kita, A.; Matsui, H.; Somoto, A.; Kimura, A.; Takata, M.; Chiba, S. Substrate specificity and subsite affinities of crystalline $\alpha$-glucosidase from Aspergillus niger. Agric. Biol. Chem. 1991, 55, 2327-2335. [CrossRef]

46. Okuyama, M.; Tanimoto, Y.; Ito, T.; Anzai, A.; Mori, H.; Kimura, A.; Matsui, H.; Chiba, S. Purification and characterization of the hyper-glycosylated extracellular $\alpha$-glucosidase from Schizosaccharomyces pombe. Enzym. Microb. Technol. 2005, 37, 472-480. [CrossRef]

47. Ernits, K.; Viigand, K.; Visnapuu, T.; Põšnograjeva, K.; Alamäe, T. Thermostability measurement of an $\alpha$-glucosidase using a classical activity-based assay and a novel Thermofluor method. Bio-Protocol 2017, 7. [CrossRef]

48. Naumov, G.I.; Naumova, E.S.; Michels, C.A. Genetic variation of the repeated MAL loci in natural populations of Saccharomyces cerevisiae and Saccharomyces paradoxus. Genetics 1994, 136, 803-812.

49. Reinders, A.; Ward, J.M. Functional characterization of the $\alpha$-glucoside transporter Sut1p from Schizosaccharomyces pombe, the first fungal homologue of plant sucrose transporters. Mol. Microbiol. 2001, 39, 445-454. [CrossRef]

50. Dujon, B.A.; Louis, E.J. Genome diversity and evolution in the budding yeasts (Saccharomycotina). Genetics 2017, 206, 717-750. [CrossRef]

51. Kelly, C.T.; Moriarty, M.E.; Fogarty, W.M. Thermostable extracellular $\alpha$-amylase and $\alpha$-glucosidase of Lipomyces starkeyi. Appl. Microbiol. Biotechnol. 1985, 22, 352-358. [CrossRef]

52. Egeter, O.; Bruckner, R. Characterization of a genetic locus essential for maltose-maltotriose utilization in Staphylococcus xylosus. J. Bacteriol. 1995, 177, 2408-2415. [CrossRef]

53. Schönert, S.; Buder, T.; Dahl, M.K. Identification and enzymatic characterization of the maltose-inducible

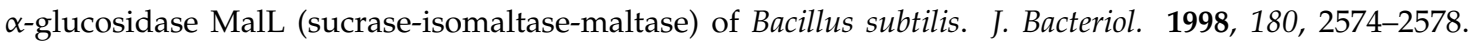
[CrossRef]

54. Rolfsmeier, M.; Blum, P. Purification and characterization of a maltase from the extremely thermophilic crenarchaeote Sulfolobus solfataricus. J. Bacteriol. 1995, 177, 482-485. [CrossRef] [PubMed] 
55. Deng, X.; Petitjean, M.; Teste, M.A.; Kooli, W.; Tranier, S.; François, J.M.; Parrou, J.L. Similarities and differences in the biochemical and enzymological properties of the four isomaltases from Saccharomyces cerevisiae. FEBS Open Bio. 2014, 4, 200-212. [CrossRef] [PubMed]

56. McWethy, S.J.; Hartman, P.A. Extracellular maltase of Bacillus brevis. Appl. Environ. Microbiol. 1979, 37, 1096-1102. [CrossRef] [PubMed]

57. Kumara, H.M.; De Cort, S.; Verachtert, H. Localization and characterization of alpha-glucosidase activity in Brettanomyces lambicus. Appl. Environ. Microbiol. 1993, 59, 2352-2358. [CrossRef]

58. Wilson, W.A.; Roach, P.J.; Montero, M.; Baroja-Fernández, E.; Muñoz, F.J.; Eydallin, G.; Viale, A.M.; Pozueta-Romero, J. Regulation of glycogen metabolism in yeast and bacteria. FEMS Microbiol. Rev. 2010, 34, 952-985. [CrossRef]

59. Casa-Villegas, M.; Marín-Navarro, J.; Polaina, J. Synthesis of isomaltooligosaccharides by Saccharomyces cerevisiae cells expressing Aspergillus niger a-glucosidase. ACS Omega 2017, 2, 8062-8068. [CrossRef]

60. Kato, N.; Suyama, S.; Shirokane, M.; Kato, M.; Kobayashi, T.; Tsukagoshi, N. Novel $\alpha$-glucosidase from Aspergillus nidulans with strong transglycosylation activity. Appl. Environ. Microbiol. 2002, 68, 1250-1256. [CrossRef]

61. Studier, F.W.; Moffatt, B.A. Use of bacteriophage T7 RNA polymerase to direct selective high-level expression of cloned genes. J. Mol. Biol. 1986, 189, 113-130. [CrossRef]

62. Curiel, J.A.; de Las Rivas, B.; Mancheño, J.M.; Muñoz, R. The pURI family of expression vectors: A versatile set of ligation independent cloning plasmids for producing recombinant His-fusion proteins. Protein Expr. Purif. 2011, 76, 44-53. [CrossRef]

63. Visnapuu, T.; Mardo, K.; Mosoarca, C.; Zamfir, A.D.; Vigants, A.; Alamäe, T. Levansucrases from Pseudomonas syringae pv. tomato and P. chlororaphis subsp. aurantiaca: Substrate specificity, polymerizing properties and usage of different acceptors for fructosylation. J. Biotechnol. 2011, 155, 338-349. [CrossRef]

64. Ernits, K.; Eek, P.; Lukk, T.; Visnapuu, T.; Alamäe, T. First crystal structure of an endo-levanase-The BT1760 from a human gut commensal Bacteroides thetaiotaomicron. Sci. Rep. 2019, 9, 8443. [CrossRef] [PubMed]

65. Mardo, K.; Visnapuu, T.; Gromkova, M.; Aasamets, A.; Viigand, K.; Vija, H.; Alamäe, T. High-throughput assay of levansucrase variants in search of feasible catalysts for the synthesis of fructooligosaccharides and levan. Molecules 2014, 19, 8434-8455. [CrossRef] [PubMed]

66. Mcilvaine, T.C. A buffer solution for colorimetric comparison. J. Biol. Chem. 1921, 49, 183-186.

67. Stingele, F.; Newell, J.W.; Neeser, J.R. Unraveling the function of glycosyltransferases in Streptococcus thermophilus Sfi6. J. Bacteriol. 1999, 181, 6354-6360. [CrossRef]

68. Jork, H.; Funk, W.; Fischer, W.; Wimmer, H. Thin-Layer Chromatography: Reagents and Detection Methods; Ebel, H.F., Ed.; VCH Verlagsgesellschaft mbH: Weinheim, Germany, 1990; Volume 1a.

69. Saitou, N.; Nei, M. The neighbor-joining method: A new method for reconstructing phylogenetic trees. Mol. Biol. Evol. 1987, 4, 406-425.

70. Kumar, S.; Stecher, G.; Li, M.; Knyaz, C.; Tamura, K. MEGA X: Molecular evolutionary genetics analysis across computing platforms. Mol. Biol. Evol. 2018, 35, 1547-1549. [CrossRef]

71. Tamura, K.; Nei, M.; Kumar, S. Prospects for inferring very large phylogenies by using the neighbor-joining method. Proc. Natl. Acad. Sci. USA 2004, 101, 11030-11035. [CrossRef]

72. Sievers, F.; Higgins, D.G. Clustal Omega for making accurate alignments of many protein sequences. Protein Sci. 2018, 27, 135-145. [CrossRef]

(C) 2020 by the authors. Licensee MDPI, Basel, Switzerland. This article is an open access article distributed under the terms and conditions of the Creative Commons Attribution (CC BY) license (http://creativecommons.org/licenses/by/4.0/). 